\title{
Groundwater Quality Assessment Plan for Single-Shell Tank Waste Management Area $U$ at the Hanford Site
}

F. N. Hodges
C. J. Chou

March 2000

Prepared for

the U.S. Department of Energy

under Contract DE-AC06-76RLO 1830

Pacific Northwest National Laboratory

Richland, Washington 99352 


\section{DISCLAIMER}

This report was prepared as an account of work sponsored by an agency of the United States Government. Neither the United States Government nor any agency thereof, nor any of their employees, make any warranty, express or implied, or assumes any legal liability or responsibility for the accuracy, completeness, or usefulness of any information, apparatus, product, or process disclosed, or represents that its use would not infringe privately owned rights. Reference herein to any specific commercial product, process, or service by trade name, trademark, manufacturer, or otherwise does not necessarily constitute or imply its endorsement, recommendation, or favoring by the United States Government or any agency thereof. The views and opinions of authors expressed herein do not necessarily state or reflect those of the United States Government or any agency thereof. 


\section{DISCLAIMER}

Portions of this document may be illegible in electronic image products. Images are produced from the best available original document. 


\section{Summary}

Waste Management Area U (WMA U), located in the 200 West Area of the Hanford Site, includes the U Tank Farm, which contains 16 single-shell tanks and their ancillary equipment and waste systems. WMA U is regulated under the Resource Conservation and Recovery Act of 1976 (RCRA) as stipulated in 40 CFR Part 265, Subpart F, which is incorporated into the Washington State dangerous waste regulations (Washington Administrative Code 173-303-400) by reference.

Groundwater monitoring has been under an interim-status indicator evaluation program. One of the indicator parameters, specific conductance, exceeded its background value in one downgradient well, triggering a change from detection monitoring to a groundwater quality assessment program. The major contributors to the higher specific conductance are nonhazardous constituents (i.e., sodium, calcium, magnesium, chloride, sulfate, and bicarbonate). Concentrations of nitrate $\left(\sim 14,500\right.$ as $\left.\mathrm{NO}_{3}{ }^{-}\right)$and chromium $(38 \mu \mathrm{g} / \mathrm{L})$ are increasing. However, the elevated nitrate and chromium concentrations are still significantly below the drinking water standard.

Groundwater flow directions at WMA $U$ have been in constant flux since the initiation of RCRA groundwater monitoring as a result of changing effluent discharge patterns within the 200 West Area. Changes in site conditions (e.g., reversal of flow direction, discharge practice) have necessitated the revision of background values to be used in the statistical evaluation. The most recent revision of background values was conducted during fiscal year 1999. The combination of lower average specific conductance values, together with a much smaller degree of variation in the upgradient wells, resulted in an $\sim 50 \%$ reduction in the critical mean value (from $\sim 533$ to $\sim 273 \mu \mathrm{S} / \mathrm{cm}$ ).

This plan presents the approach to be used for the groundwater quality assessment program. Based on the results of this investigation, if WMA U is not the source of groundwater contamination, the site will revert to detection monitoring. If WMA $U$ is the source, then a second part of the groundwater quality assessment plan will be prepared to define the rate and extent of migration of contaminants in the

groundwater and their concentrations. Information gathered will enhance the understanding of subsurface conditions and processes to support tank waste remediation and cleanup decisions and/or complement near-term corrective actions to protect groundwater and the Columbia River. 



\section{Contents}

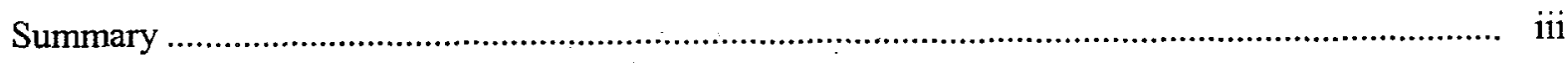

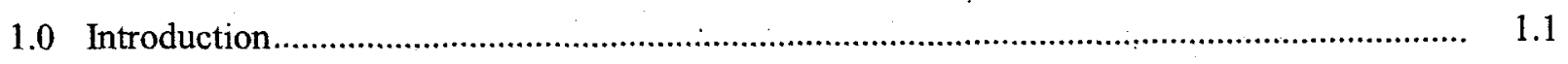

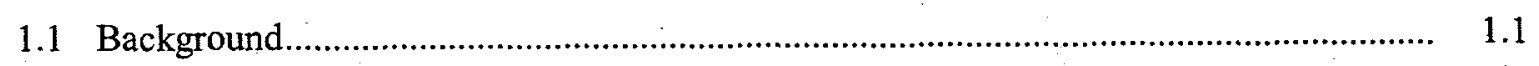

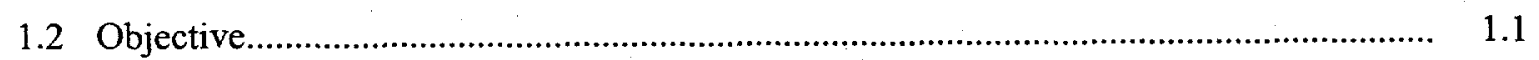

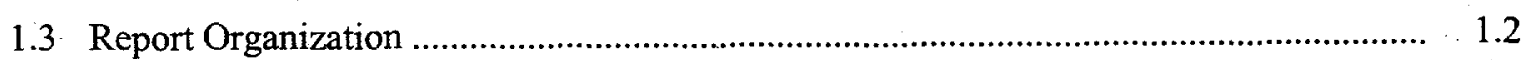

2.0 Facility Description and Waste Characteristics ...................................................... 2.1

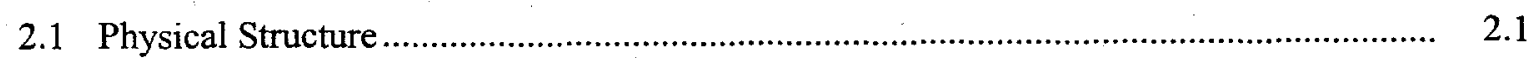

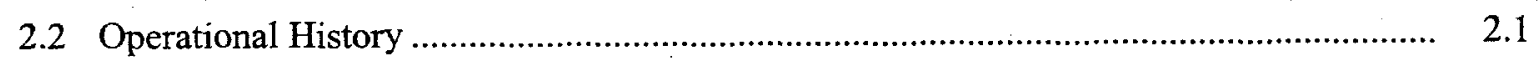

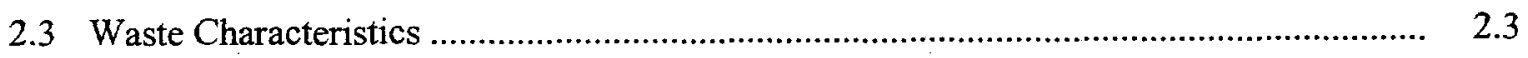

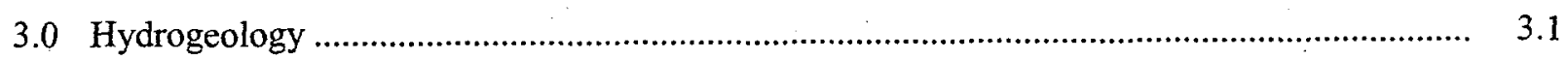

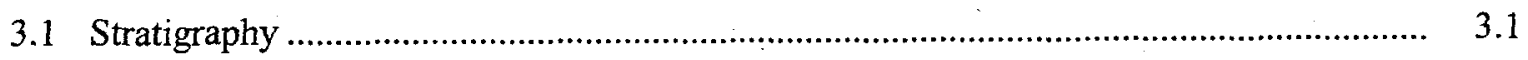

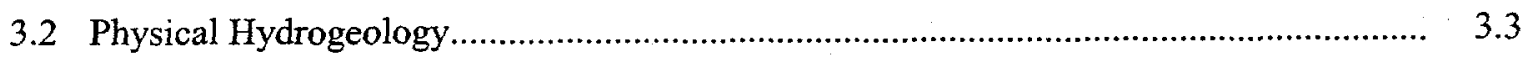

4.0 Evaluation of Specific Conductance Data ...........................................................

4.1 Statistical Evaluation Method............................................................................ 4.1

4.2 Evaluation of 'Specific Conductance Data ............................................................ 4.2

5.0 Groundwater Quality Assessment Program .......................................................... 5.1

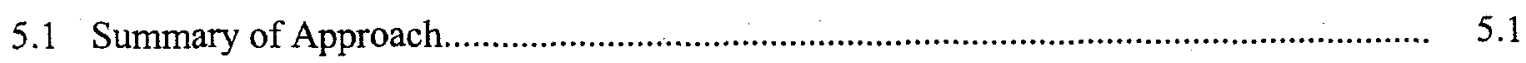

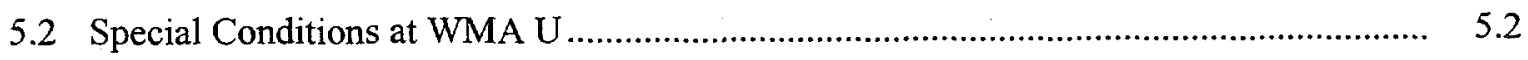

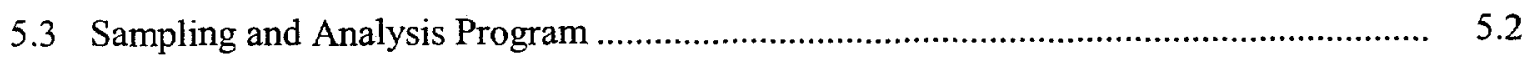

5.3.1 Monitoring Well Network ......................................................................... 5.2

5.3.2 Constituent List and Sampling Frequency.................................................. 5.3

5.3.3 Determination of Groundwater Flow Directions .............................................. 5.4

5.3.4 Sampling and Analysis Protocol .................................................................... 5.4

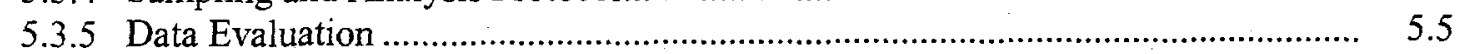

5.3.6 Quality Assurance and Quality Control.......................................................... 5.5

5.3.7 Schedule of Implementation ..................................................................... 5.5 
6.0 Data Management, Evaluation, and Reporting

6.1 Data Management.

6.1

6.2 Interpretation

6.1

6.3. Reporting

6.2

7.0 References.

7.1

Appendix - Well Construction and Completion Summaries

A.1 


\section{Figures}

1.1 Map Showing Location of Waste Management Area U in the 200 West Area of the Hanford Site

2.1 Map of Waste Management Area U, Showing Locations of Waste Tanks, Monitoring Wells, and Miscellaneous Structures

3.1 Generalized Stratigraphic Column for the Suprabasalt Sediments Beneath the 200 West Area

3.2 Hydrograph for Well 299-W19-1

3.3 Hydrographs for RCRA Monitoring Wells at Waste Management Area U

3.4 Water-Table Map for Vicinity of Waste Management Area U

4.1 Specific Conductance Concentration Versus Time at Monitoring Wells for Waste Management Area U.

\section{Tables}

2.1 Selected Waste Constituents and Average Compositions in the Tanks for Waste Management Area U

4.1 Critical Means for 20 Comparisons--Background Contamination Indicator Parameter Data for Waste Management Area U

4.2 Critical Means for 20 Comparisons--Background Contamination Indicator Parameter Data for Waste Management Area U

4.3 Critical Means for 20 Comparisons--Background Contamination Indicator Parameter Data for Waste Management Area U....

4.4 Milliequivalents in Recent Waste Management Area U Groundwater Samples

5.1 Wells in Monitoring Network.

5.2 Constituent List.

6.1 Reports Required for Compliance with 40 CFR 265, Subpart F, for Groundwater Monitoring 


\subsection{Introduction}

\subsection{Background}

The Hanford Federal Facility Agreement and Consent Order (commonly known as the Tri-Party Agreement; Ecology et al. 1989) placed the single-shell tank farms under Resource Conservation and Recovery Act of 1976 (RCRA) interim-status regulation. This agreement also placed the interim-status sites under the supervision of the Washington State Department of Ecology (Ecology).

Waste Management Area U (WMA U) includes the U Tank Farm, which contains 16 single-shell tanks (constructed in 1943-1944) and their ancillary equipment and waste systems (e.g., transfer lines, diversion boxes). WMA U is located in the 200 West Area (Figure 1.1) and is currently regulated under RCRA interim-status regulations as stipulated in 40 CFR Part 265, Subpart F, which is incorporated into the Washington State dangerous waste regulations (Washington Administrative Code [WAC] 173-303400 ) by reference.

A RCRA Part A (interim-status) permit application and closure/work plan was submitted in 1989 (DOE 1989). Under the Tri-Party Agreement, as amended, the single-shell tank farm WMAs are scheduled for closure under Washington State final-status regulations (WAC 173-303-610). The time and method of closure are uncertain, but closure will probably be post-2030.

Groundwater monitoring has been under an interim-status indicator evaluation program that compared general contaminant indicator parameters from downgradient wells to background values established from upgradient wells. One of the indicator parameters, specific conductance, exceeded its background value in one downgradient well, 299-W19-41, triggering a change from detection monitoring to a groundwater quality assessment program.

Major contributors to the higher specific conductance are nonhazardous constituents (i.e., sodium, calcium, magnesium, chloride, sulfate, and bicarbonate). Their elevated concentrations may be related to enhanced water infiltration along the southern boundary of the WMA. However, additional information is needed to confirm or refute this hypothesis. This plan presents the investigatory approach used by Pacific Northwest National Laboratory ${ }^{(a)}$ for the assessment program.

\subsection{Objective}

The objective of the first phase of this assessment program is to determine, as allowed under $40 \mathrm{CFR}$ 265.93(d)(5), whether the increased concentrations of nitrate and chromium in groundwater are from WMA U or from an upgradient source. Based on the results of the first determination, if WMA U is not the source of groundwater contamination, then the site will revert to detection monitoring. If WMA $U$ is

(a) Pacific Northwest National Laboratory is operated by Battelle for the U.S. Department of Energy. 


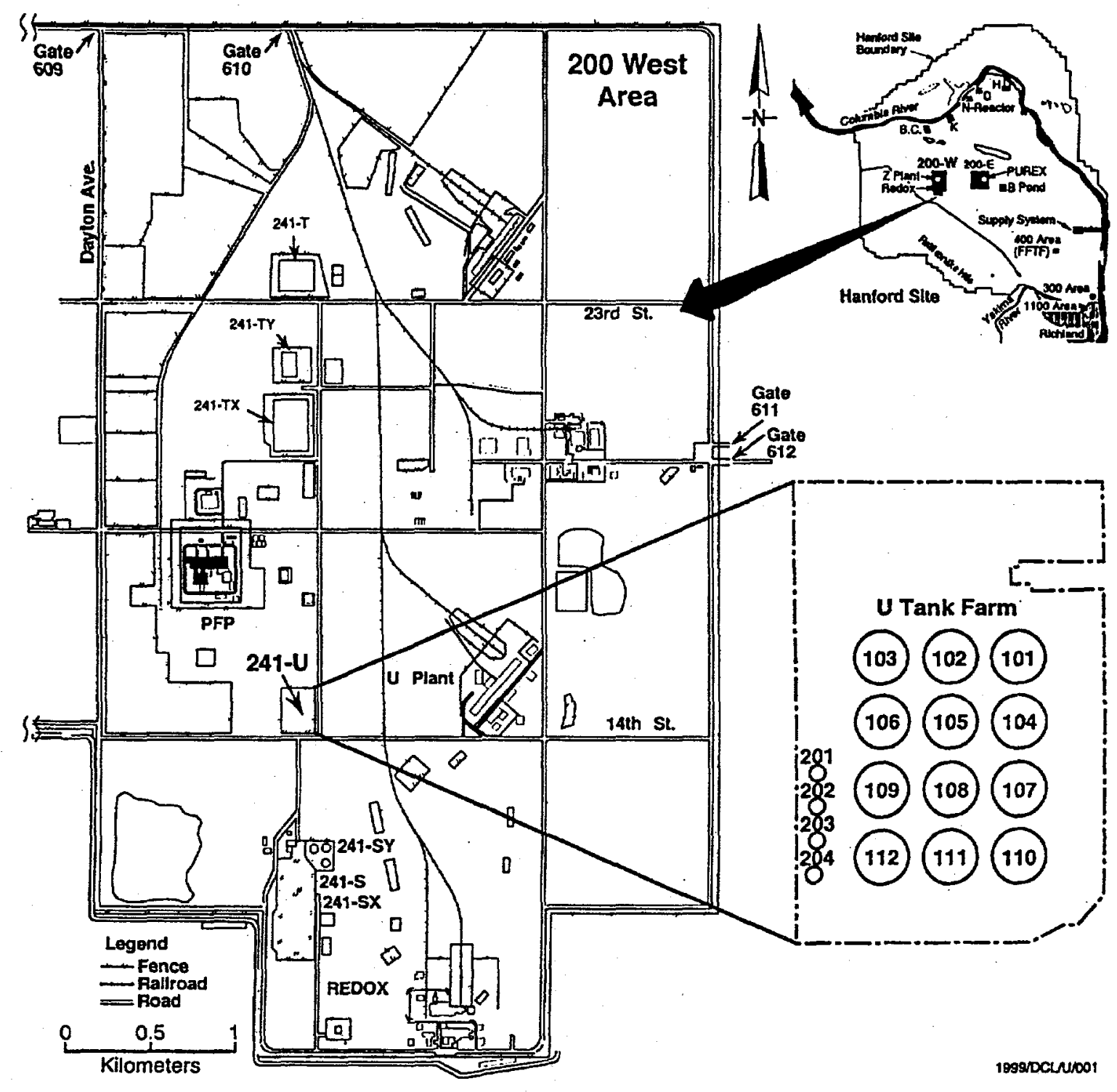

Figure 1.1. Map Showing Location of Waste Management Area U in the 200 West Area of the Hanford Site

the source, then a second part of the groundwater quality assessment plan will be prepared to define the rate and extent of migration of contaminants in the groundwater and their concentrations ( $40 \mathrm{CFR}$ $265.93[\mathrm{~d}][4])$.

\subsection{Report Organization}

In addition to this introduction, this report consists of a description of the facility and the wastes disposed therein (Chapter 2.0), the hydrogeology of the area (Chapter 3.0), an evaluation of the indicator parameter that caused this assessment program (Chapter 4.0), and a description of the ensuing quality 
assessment program for this WMA (Chapter 5.0). How the data gathered from the monitoring of this area is treated is given in Chapter 6.0, and the references cited in the text are given in Chapter 7.0. An appendix provides the as-built drawings of the wells used for monitoring this WMA. 


\subsection{Facility Description and Waste Characteristics}

\subsection{Physical Structure}

WMA U is located in the south-central portion of the Hanford Site's 200 West Area (see Figure 1.1). The WMA, with an area of $30,000 \mathrm{~m}^{2}\left(323,000 \mathrm{ft}^{2}\right)$, contains 16 single-shell carbon steel tanks constructed between 1943 and 1944 (Figure 2.1). Twelve of the tanks (U-101 through U-112) have capacities of $2,017,000 \mathrm{~L}(533,000 \mathrm{gal})$ and four (U-201 through U-204) have capacities of 208,000 L $(55,000 \mathrm{gal})$.

The tanks are constructed with a concrete shell and a single-walled liner of carbon steel. The tanks are $22.9 \mathrm{~m}$ ( $75 \mathrm{ft})$ in diameter and are $\sim 9 \mathrm{~m}(29.5 \mathrm{ft})$ in height. The tanks are set with the bottoms $\sim 11 \mathrm{~m}$ ( $37 \mathrm{ft}$ ) below grade with $\sim 2 \mathrm{~m}(7 \mathrm{ft})$ of fill over the top. Various ports in the tank tops are available for waste transfer and monitoring. In addition, vadose zone monitoring wells (dry wells) are located in the fill material around the tanks to allow monitoring of radionuclide migration around the tanks. The smaller $(208,000-\mathrm{L}[55,000$-gal] $)$ tanks are $6.1 \mathrm{~m}(20 \mathrm{ft})$ in diameter and $\sim 7.8 \mathrm{~m}(25.5 \mathrm{ft})$ in height. The bottoms are at $\sim 11.3 \mathrm{~m}(37.25 \mathrm{ft})$ below grade and $\sim 3.6 \mathrm{~m}(11.75 \mathrm{ft})$ of fill cover the tanks. Additional details on tank construction are available in Anderson (1990).

\subsection{Operational History}

The tanks began receiving waste in 1946 (Anderson 1990) and were in more-or-less continual use from that time until 1980. The first waste sent to the U Tank Farm was "metal waste" resulting from the bismuth phosphate process at $\mathrm{B}$ and $\mathrm{T}$ Plants. Most of the metal waste was subsequently removed from the tanks and recycled through U Plant to remove uranium. The metal waste was replaced by waste from the Reduction Oxidation (REDOX) Plant and from other waste operations. Wastes were transferred between tanks and tank farms throughout the operational history, and, as a result, there is considerable uncertainty about the exact compositions of waste in the tanks at any particular time. Anderson (1990) provides information on tank histories, and historical information on the chemistry of waste disposed to the tanks is provided by Kupfer et al. 1999. Agnew (1997) provides an estimate of current tank waste compositions based on their mixing histories.

Waste was cascaded between tanks at WMA U; however, apparently none was cascaded to cribs or ditches. Four of the tanks in the WMA (U-101, U-104, U-110, and U-112) have been declared leakers (Anderson 1990, DOE 1992, Hanlon 1996). There is considerable uncertainty in reported leak volumes; however, the two most serious leaks involved tanks U-101 and U-104. Tank U-101, declared a leaker in 1959 , apparently leaked $\sim 114,000 \mathrm{~L}(\sim 30,000$ gal) of waste. Tank U-104, declared a leaker in 1956, apparently leaked $\sim 208,000 \mathrm{~L}(55,000 \mathrm{gal})$ of waste. Tank U-110, declared a leaker in 1975 , leaked $\sim 31,000 \mathrm{~L}(\sim 8,200)$ of waste. Tank U-112 was declared a leaker in 1969 . There is considerable uncertainty concerning the volume leaked from tank U-112, which may have been as high as $32,000 \mathrm{~L}$ $(8,400 \mathrm{gal})$. All four leakers have been stabilized and contain little or no pumpable liquid. 


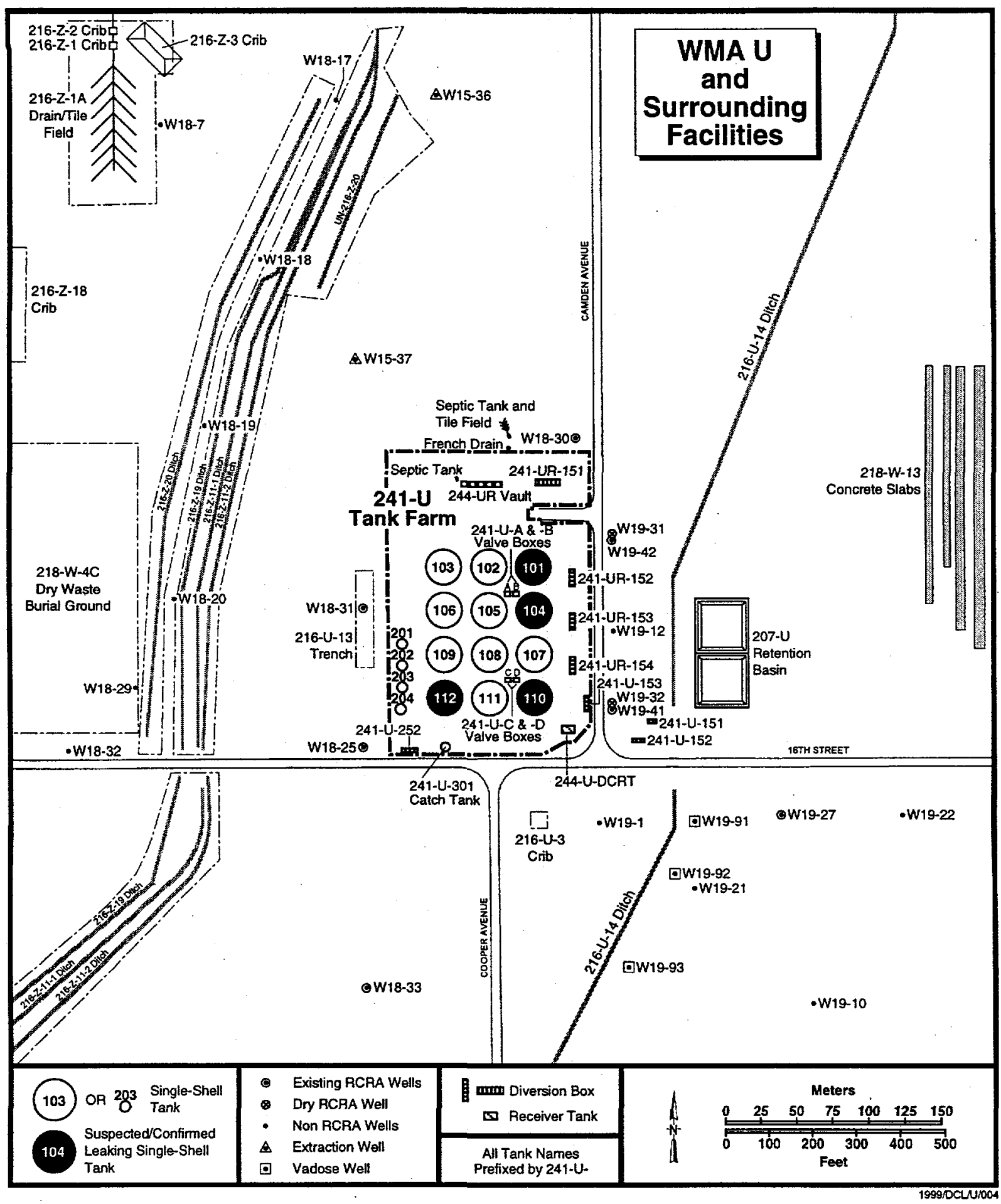

Figure 2.1. Map of Waste Management Area U, Showing Locations of Waste Tanks, Monitoring Wells, and Miscellaneous Structures. RCRA downgradient wells 299-W19-31 and 299-W19-32 are no longer sampleable and are included for historical reasons. 
Four unplanned releases have been documented (DOE 1992). The waste volumes associated with these unplanned releases are unknown. The three releases that may have had significant impact were a beta contamination in the vicinity of the 241-U-151 and 241-U-152 diversion boxes east of the WMA ( $20 \mathrm{mr} / \mathrm{h}$ at surface), a "violent chemical reaction" in a vat at the $244-\mathrm{UR}$ vault that spread first-cycle metal waste contamination over an unspecified area, and a ruptured waste line at tank U-103. DOE (1997) reported significant surface contamination within the tank farm and evidence for several unreported releases.

The 216-U-13 trench, located immediately east of the tank farm fence (see Figure 2.1), was a facility for steam cleaning and decontaminating vehicles and never received tank waste. The trench was stabilized by removal of contaminated soil and backfilling with clean fill (DOE 1992).

\subsection{Waste Characteristics}

The principal waste sent to the U Tank Farm, both from the bismuth phosphate process at B and $T$ Plants and from the REDOX process, consisted of nitric acid waste solution from the plutonium removal process that was subsequently over-neutralized with sodium hydroxide and sodium carbonate. The result was a high-pH sodium nitrate solution and contained other process chemicals, fission products, and residual actinides. Early bismuth phosphate waste contained large quantities of uranium that was subsequently removed by secondary processing at U Plant. Average total concentrations and activities, as well as ratios in the tanks in relation to the drinking water standard or maximum contaminant level for selected components in the waste at WMA $U$, are presented in Table 2.1. Values used in arriving at these unweighted averages are from Agnew (1997). The values represent bulk tank concentrations and do not distinguish between liquid and solid phases within the tanks.

As shown in Table 2.1, the tank waste is a mixed waste with a wide range of chemical and radiological constituents. In terms of chemical constituents, however, only a few are RCRA regulated and have sufficient concentration and mobility to present a potential for groundwater contamination at this time. Principal among these are nitrate, chromium (hexavalent), and fluoride. Nitrite and ammonium are present in significant quantities; however, they are rarely detected in Hanford Site groundwater and are probably converted to nitrate by bacterial action within the vadose zone.

A number of the tanks also contain significant concentrations of organic chemicals, principally complexants used during plutonium removal. These are not listed hazardous wastes but are mobile and, through elevated total organic carbon (TOC), should aid in identifying contaminants originating from the tanks. There is no evidence for significant quantities of chlorinated hydrocarbons in tank waste at WMA U; thus, total organic halides (TOX) are of little or no use in indicating contamination from tank waste within the WMA.

In addition to the chemical constituents, the tank waste contains a wide variety of radioactive constituents, including cesium-137, strontium-90, cobalt-60, tritium, technetium-99, iodine-129, selenium-79, and neptunium-237, along with several isotopes of uranium and plutonium (see Table 2.1). From the perspective of transport, the most important indicators are tritium, technetium-99, and iodine- 129 . 
Table 2.1. Selected Waste Constituents and Average Compositions in the Tanks for Waste Management Area U (calculated from values for individual tanks in Agnew 1997)

\begin{tabular}{|c|c|c|}
\hline Waste Component & $\begin{array}{l}\text { Average Concentration } \\
\text { or Activity in the Tanks }\end{array}$ & $\begin{array}{l}\text { Concentration or Activity } \\
\text { Divided by DWS or MCL }\end{array}$ \\
\hline Sodium & $1.5 \times 10^{8} \mu \mathrm{g} / \mathrm{L}$ & (a) \\
\hline Calcium & $1.6 \times 10^{6} \mu \mathrm{g} / \mathrm{L}$ & (a) \\
\hline Chromium & $2.6 \times 10^{6} \mu \mathrm{g} / \mathrm{L}$ & 26,000 \\
\hline Nitrate & $1.4 \times 10^{8} \mu \mathrm{g} / \mathrm{L}$ & 3,111 \\
\hline Nitrite & $4.46 \times 10^{7} \mu \mathrm{g} / \mathrm{L}$ & 13,500 \\
\hline Ammonium & $6.68 \times 10^{5} \mu \mathrm{g} / \mathrm{L}$ & (a) \\
\hline Sulfate & $1.7 \times 10^{7} \mu \mathrm{g} / \mathrm{L}$ & 34 \\
\hline Chloride & $3.0 \times 10^{6} \mu \mathrm{g} / \mathrm{L}$ & (a) \\
\hline Fluoride & $6.2 \times 10^{5} \mu \mathrm{g} / \mathrm{L}$ & 155 \\
\hline Phosphate & $1.3 \times 10^{7} \mu \mathrm{g} / \mathrm{L}$ & (a) \\
\hline Carbon-14 & $2.02 \times 10^{7} \mathrm{pCi} / \mathrm{L}$ & 10,100 \\
\hline Cesium-137 & $1.59 \times 10^{11} \mathrm{pCi} / \mathrm{L}$ & $795,000,000$ \\
\hline Strontium-90 & $7.83 \times 10^{10} \mathrm{pCi} / \mathrm{L}$ & $9,790,000,000$ \\
\hline Tritium & $1.4 \times 10^{8} \mathrm{pCi} / \mathrm{L}$ & 7,000 \\
\hline Cobalt-60 & $2.2 \times 10^{7} \mathrm{pCi} / \mathrm{L}$ & 220,000 \\
\hline Technetium-99 & $1.4 \times 10^{8} \mathrm{pCi} / \mathrm{L}$ & 155,555 \\
\hline Selenium-79 & $2.01 \times 10^{6} \mathrm{pCi} / \mathrm{L}$ & (a) \\
\hline Iodine-129 & $2.7 \times 10^{5} \mathrm{pCi} / \mathrm{L}$ & 270,000 \\
\hline Uranium-232 & $4.15 \times 10^{5} \mathrm{pCi} / \mathrm{L}$ & (a) \\
\hline Uranium-233 & $1.59 \times 10^{6} \mathrm{pCi} / \mathrm{L}$ & (a) \\
\hline Uranium-234 & $2.05 \times 10^{7} \mathrm{pCi} / \mathrm{L}$ & (a) \\
\hline Uranium-235 & $9.1 \times 10^{5} \mathrm{pCi} / \mathrm{L}$ & (a) \\
\hline Uranium-236 & $2.02 \times 10^{5} \mathrm{pCi} / \mathrm{L}$ & (a) \\
\hline Uranium-238 & $2.06 \times 10^{7} \mathrm{pCi} / \mathrm{L}$ & (a) \\
\hline Uranium & $2.52 \times 10^{5} \mu \mathrm{g} / \mathrm{L}$ & 12,600 \\
\hline Neptunium-237 & $5.19 \times 10^{5} \mathrm{pCi} / \mathrm{L}$ & 34,600 \\
\hline Plutonium-238 & $6.71 \times 10^{6} \mathrm{pCi} / \mathrm{L}$ & 44,700 \\
\hline Plutonium-239 & $3.85 \times 10^{8} \mathrm{pCi} / \mathrm{L}$ & $25,700,000$ \\
\hline Plutonium-240 & $5.52 \times 10^{7} \mathrm{pCi} / \mathrm{L}$ & $3,680,000$ \\
\hline Plutonium-241 & $3.72 \times 10^{8} \mathrm{pCi} / \mathrm{L}$ & $24,800,000$ \\
\hline Plutonium-242 & $1.6 \times 10^{3} \mathrm{pCi} / \mathrm{L}$ & 107 \\
\hline Americium-241 & $3.4 \times 10^{6} \mathrm{pCi} / \mathrm{L}$ & 227,000 \\
\hline Americium-243 & $3.92 \times 10^{3} \mathrm{pCi} / \mathrm{L}$ & 261 \\
\hline Curium-242 & $3.14 \times 10^{5} \mathrm{pCi} / \mathrm{L}$ & 20,900 \\
\hline Curium-243 & $1.33 \times 10^{4} \mathrm{pCi} / \mathrm{L}$ & 887 \\
\hline Curium-244 & $1.78 \times 10^{5} \mathrm{pCi} / \mathrm{L}$ & 11,900 \\
\hline
\end{tabular}




\subsection{Hydrogeology}

\subsection{Stratigraphy}

WMA $U$ is underlain by $\sim 150 \mathrm{~m}$ (490 ft) of suprabasalt sediments. The major sedimentary units underlying the WMA are the Ringold Formation and the Hanford formation. The Pliocene-Pleistocene unit occurs between the Ringold Formation and the Hanford formation. A generalized stratigraphic column is presented in Figure 3.1.

The Ringold Formation consists of Miocene-Pliocene fluvial and lacustrine clastic sediments deposited by the ancestral Columbia River system. The sediments rest unconformably on the Miocene-age Columbia River Basalt Group. Lindsey (1995), using a depositional environment approach, identified a number of facies within the Ringold Formation. Using facies associations, Lindsey divided the Ringold Formation into three informal members. The Ringold Formation underlying WMA U belongs entirely to the Member of Wooded Island, the lowest member of the formation. Lindsey divided the Member of Wooded Island into five gravel-dominated fluvial depositional units, separated by widespread overbank, paleosol, and lacustrine deposits. The lower mud unit, a thick lacustrine deposit, separates gravel unit A from the overlying deposits.

The Plio-Pleistocene unit, which separates the Ringold Formation from the Hanford formation, was divided into two distinct sequences by Singleton and Lindsey (1994). The upper sequence of thinly laminated silts was identified as lacustrine deposits. Calcium carbonate-rich strata characterize the lower sequence. This lower interval consists of locally derived basaltic detritus, silt-rich eolian deposits, reworked Ringold material, and calcium carbonate-rich paleosols. The calcium carbonate occurs as thin $(<2.5-\mathrm{cm}[<1-\mathrm{ft}])$ layers, nodules, and coatings on clasts. Singleton and Lindsay also state that examination of geologic logs, split-tube samples, and cores "suggest that the well-cemented carbonate horizons may be discontinuous and highly fractured." This latter observation is important in assessing the role of the Plio-Pleistocene unit in retarding water flow through the vadose zone in this area.

The Hanford formation is an informal stratigraphic unit made up of uncemented gravel, sand, and silt deposited by the late Pleistocene Missoula glacial floods (Fecht et al. 1987, DOE 1988, Baker et al. 1991). Singleton and Lindsey (1994) described the Hanford formation in terms of three gradational facies: gravel dominated, sand dominated, and silt dominated. At both the 216-U-14 ditch (Singleton and Lindsey 1994) and at WMA U (Horton and Hodges 1999), the upper portion of the Hanford formation is gravel dominated and the lower portion is sand and silt dominated. At WMA U, the upper, graveldominated unit is $\sim 16 \mathrm{~m}$ (53 ft) thick, and the Hanford formation has a total thickness of $\sim 35 \mathrm{~m}(115 \mathrm{ft})$.

The entire suprabasalt sequence is penetrated in well 299-W19-10 (also known as DH-7), located $\sim 275 \mathrm{~m}(900 \mathrm{ft}$ ) southeast of the southeastern corner of WMA U (see Figure 2.1). In this well, the top of basalt occurs at a depth of $170 \mathrm{~m}(557 \mathrm{ft}$ ). Interpretation of core from well 299-W19-10 (Lindsay 1995 ) indicates that Ringold unit $A$, below the lower mud unit, is $\sim 23 \mathrm{~m}$ ( $75 \mathrm{ft}$ thick). The lower mud 


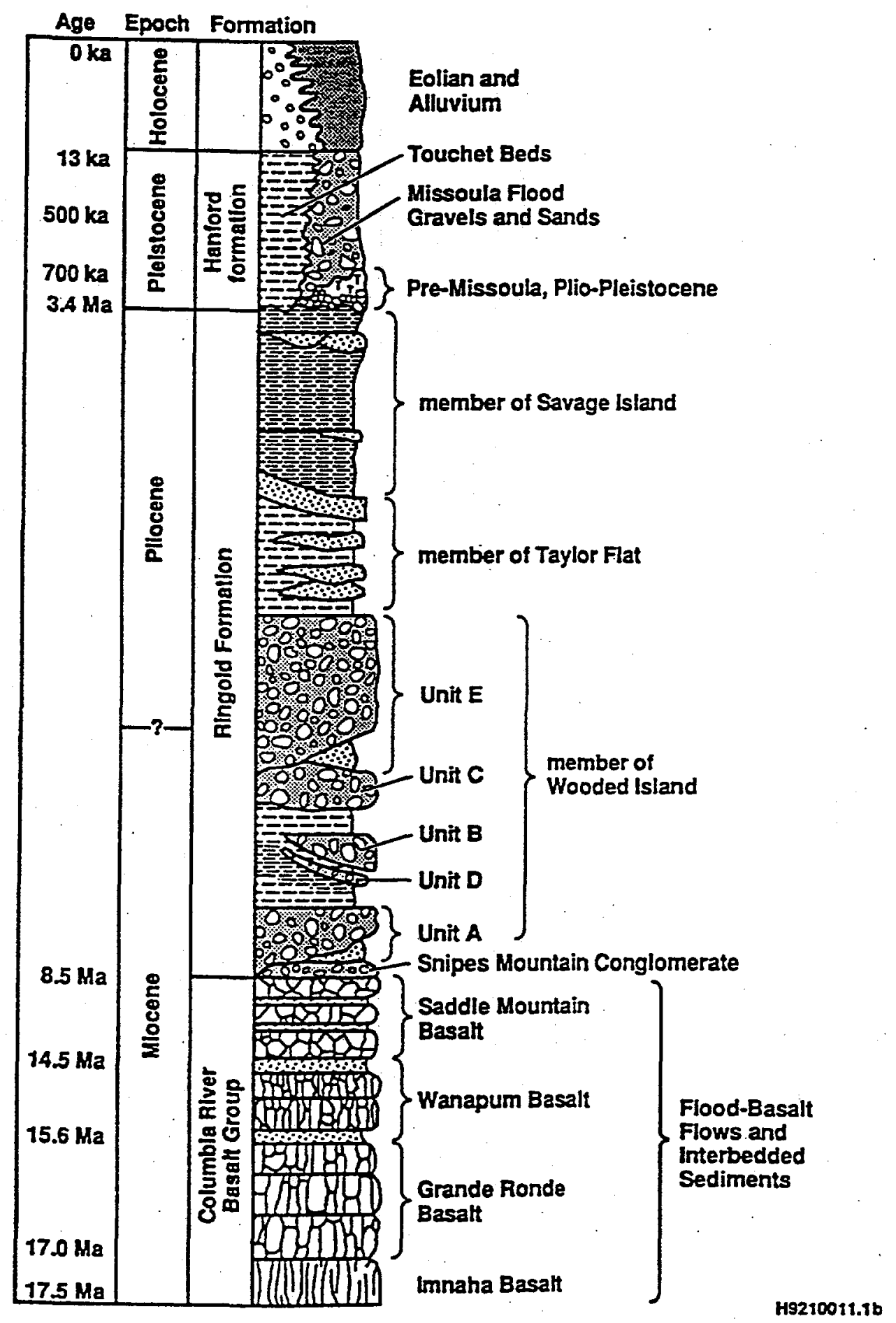

Figure 3.1. Generalized Stratigraphic Column for the Suprabasalt Sediments Beneath the 200 West Area (Lindsey 1995) 
unit, a prominent lacustrine deposit near the base of the Ringold Formation is $\sim 10 \mathrm{~m}$ ( $33 \mathrm{ft}$ thick).

Ringold unit $\mathrm{E}$, between the lower mud and the Plio-Pleistocene unit, has a thickness of $\sim 90 \mathrm{~m}$ ( $295 \mathrm{ft}$ ). The upper $50 \mathrm{~m}$ (164 ft) of core were not recovered in well 299-W19-10; thus, the thickness of the PlioPleistocene unit is not available from this well. However, geologic and geophysical logs for the two wells

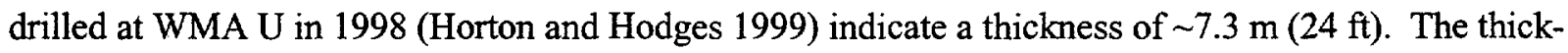
ness of the Hanford formation beneath the WMA is $\sim 35 \mathrm{~m}(116 \mathrm{ft})$.

\subsection{Physical Hydrogeology}

The water table beneath WMA U occurred at an elevation of $\sim 137 \mathrm{~m}$ (450 ft) in December 1998.

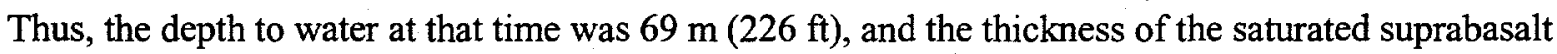

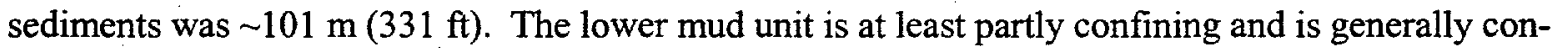
sidered the base of the unconfined aquifer in this area. On this basis, the thickness of the unconfined aquifer is $\sim 68 \mathrm{~m}$ (223 ft). Singleton and Lindsey (1994) reported perched water beneath the 216-U-14 ditch as a result of disposal of large quantities of water to that facility; however, no evidence for perched water has been reported during drilling at WMA $U$.

Slug tests in RCRA monitoring wells have yielded a range of values for hydraulic conductivity from 1.1 to $11.2 \mathrm{~m} / \mathrm{d}(3.5$ to $36.6 \mathrm{ft} / \mathrm{d}$ ). Caggiano (1994) reported hydraulic conductivity values of $1.9 \mathrm{~m} / \mathrm{d}$ $(6.1 \mathrm{ft} / \mathrm{d})$ for upgradient well 299-W18-25 and $11.2 \mathrm{~m} / \mathrm{d}(36.6 \mathrm{ft} / \mathrm{d})$ for downgradient well 299-W19-31. Slug tests carried out in wells drilled in 1998 exhibited a similar range of values. Tests carried out in well 299-W19-41 yielded hydraulic conductivity values between 1.1 and $1.5 \mathrm{~m} / \mathrm{d}$ ( 3.5 and $5 \mathrm{ft} / \mathrm{d})$, and tests in well 299-W19-42, adjacent to well 299-W19-31, yielded hydraulic conductivity values between 7.3 and $10.7 \mathrm{~m} / \mathrm{d}$ ( 24 and $35 \mathrm{ft} / \mathrm{d}$ ). The variability between wells indicates differing degrees of cementation, compaction, and/or sorting within the Ringold Formation and indicates the potential for preferred flow. zones within the upper portion of the unconfined aquifer. The current data indicate horizontal variability; however, data from other sites in the 200 West Area indicate that vertical variability is also present.

The rate of groundwater flow, $v$, within the unconfined aquifer beneath WMA $U$ is highly uncertain. The equation

$$
\mathrm{v}=\mathrm{Ki} / \mathrm{n}_{\mathbf{e}}
$$

where $\quad \mathrm{K}=$ hydraulic conductivity

$\mathrm{i}=$ hydraulic gradient

$\mathrm{n}_{\mathrm{e}}=$ effective porosity

can be used to estimate the so-called "Darcy velocity;" however, this equation requires a value for effective porosity, a largely unknown parameter. Graham et al. (1981) estimated that the effective porosity for the Ringold Formation is somewhere in the range 0.1 to 0.3 , which is still the best available estimate. The hydraulic gradient in December 1998 was $\sim 0.002$. Using the measured range of hydraulic conductivities, the estimated range of effective porosities, and the December 1998 hydraulic gradient yields estimated 
groundwater flow rates ranging from 0.007 to $0.22 \mathrm{~m} / \mathrm{d}(0.02$ to $0.74 \mathrm{ft} / \mathrm{d})$. It should be noted, however, that during much of the RCRA monitoring period the hydraulic gradient was less than the current (i.e., December 1998) value.

Historically, water levels and flow directions at WMA U have been dominated by discharges to the 216-U-10 pond, located $\sim 450 \mathrm{~m}$ (1475 ft) southeast of WMA U. Effluent discharge to U Pond resulted in a 26-m (85-ft) mound on the water table (Graham et al. 1981) and a northeasterly flow direction at WMA U. U Pond was decommissioned in 1984 and, as a result, water levels dropped rapidly across a significant portion of the 200 West Area. Figure 3.2, a hydrograph for well 299-W19-1 (see Figure 2.1 for location), illustrates the effect of U Pond on water-table elevations in the vicinity of WMA U. Between June

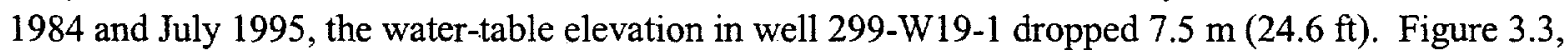
hydrographs for the RCRA monitoring wells at WMA U, shows the further decline of the water table.

A water-table map for the vicinity of WMA U is presented in Figure 3.4. This water-table map, based on March 1999 data, indicates an east or northeast groundwater flow direction. The flow directions indicated in Figure 3.4 represent the latest in a series of groundwater flow directions at the WMA that resulted from changing effluent discharge patterns in the 200 West Area through the 1980s and 1990s. These changes and their causes are discussed below.

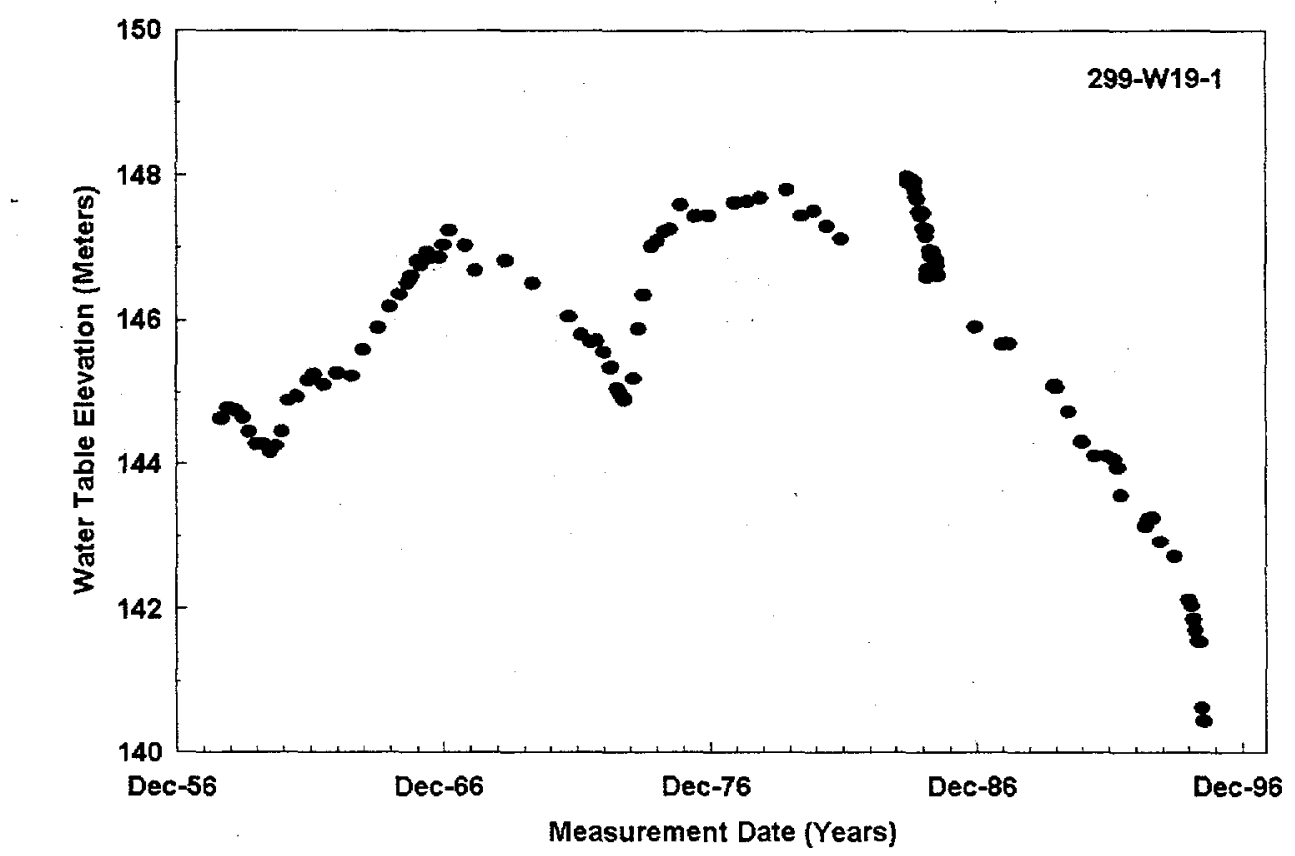

Figure 3.2. Hydrograph for Well 299-W19-1 (elevations in meters above mean sea level) 


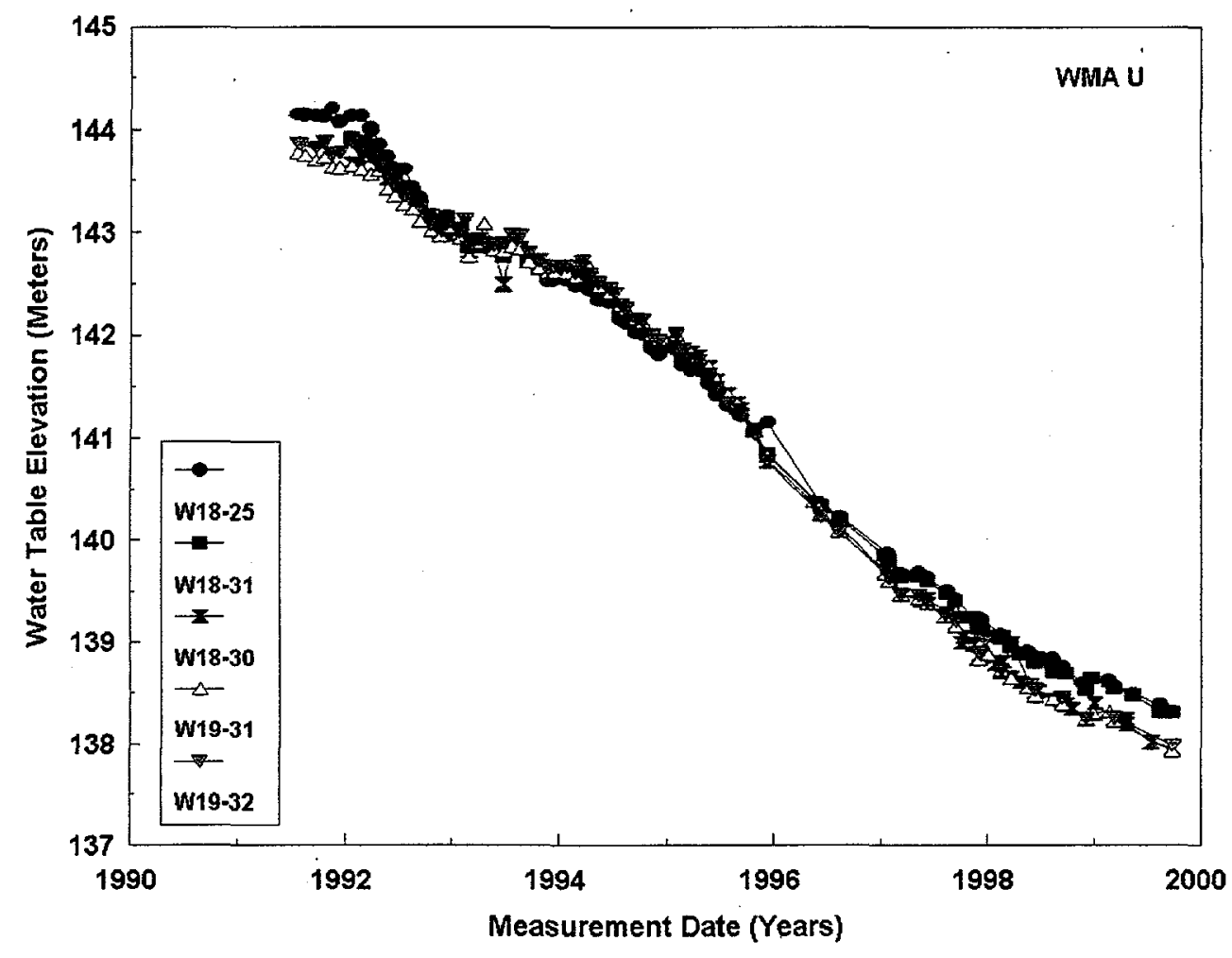

Figure 3.3. Hydrographs for RCRA Monitoring Wells at Waste Management Area U (elevations in meters above mean sea level)

After cessation of discharge to U Pond in 1984, discharge continued at the Plutonium Finishing Plant. Because of this discharge, the U Pond mound declined more slowly in the vicinity of the Plutonium Finishing Plant, resulting in a northward migration of the high point of the mound as the mound decreased. This northward migration of the high point of the groundwater mound resulted in a shift in groundwater flow direction, first to the east and then to the southeast.

In the 1991-1993 time period, two major effluent discharges to the 216-U-14 ditch, southeast of WMA U, resulted in a temporary reversal of flow directions at the WMA. This reversal is apparent in the hydrographs in Figure 3.3, with upgradient wells 299-W18-25 and 299-W18-31 becoming downgradient wells in early 1993 and then resuming their upgradient identities in 1996 as groundwater flow swung back around toward the east.

The discharges to the 216-U-14 ditch described by Singleton and Lindsey (1994) peaked in 1991 and 1993, producing at least a 15-m (50-ft) increase in the perched water table beneath the ditch. The 1991 discharge was the larger of the two, and the effects on the water table are apparent in the earliest monitoring data for the WMA. However, given the uncertainty in paths to groundwater and in travel times through the vadose zone, it is not possible to separate the effects of the two events.

Phase 3 of the 200-ZP-1 Operable Unit pump-and-treat operation started in August 1997 (DOE 1998). This pump-and-treat operation, designed to stabilize the carbon tetrachloride plume that results from 


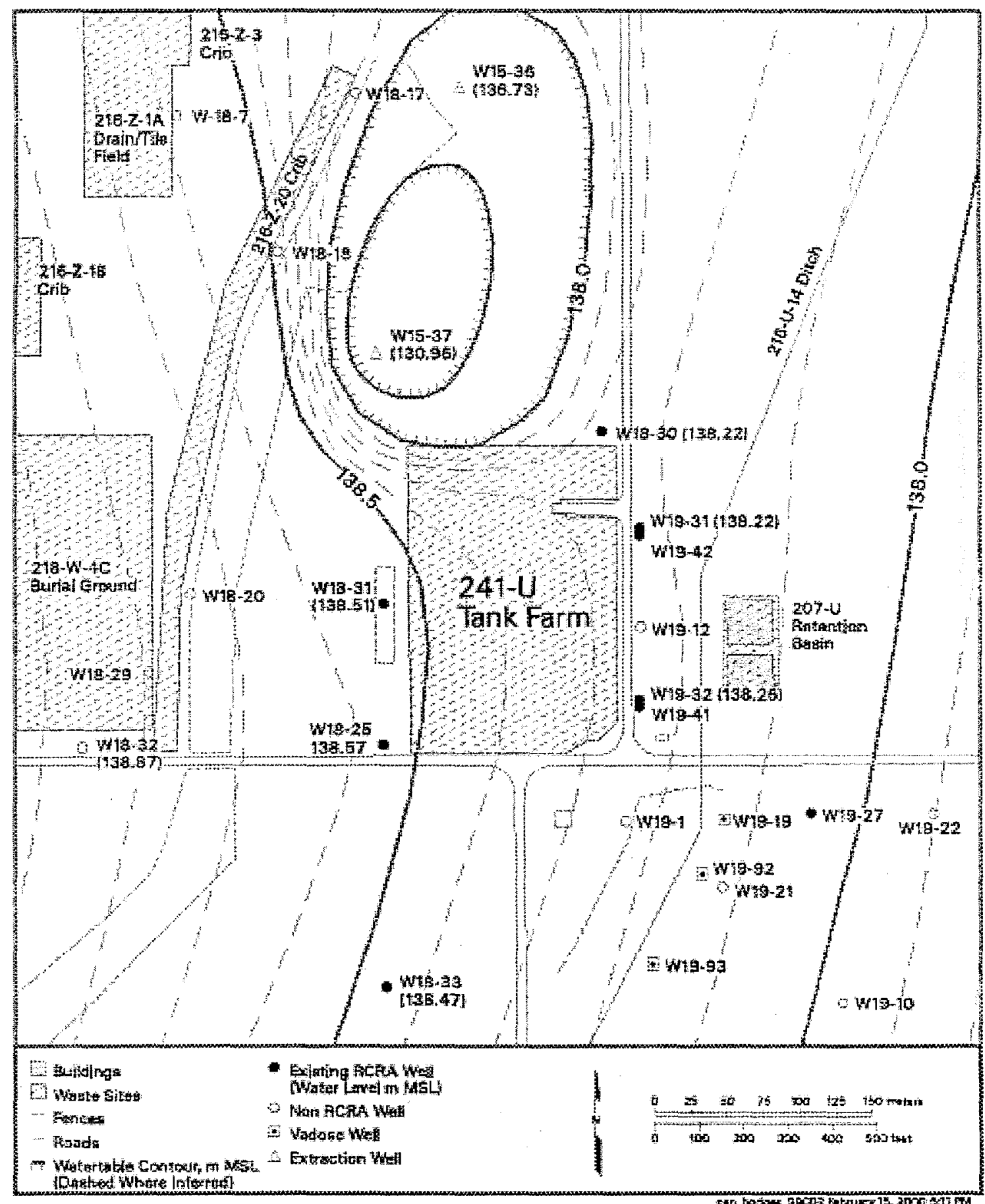

Figure 3.4. Water-Table Map (March 1999 data) for Vicinity of Waste Management Area U (elevations in meters above mean sea level) 
disposal to cribs near the Plutonium Finishing Plant, extracts contaminated groundwater from a series of wells east of the Plutonium Finishing Plant, between WMAs U and TX-TY to the north. The nearest of the extraction wells for the pump-and-treat operation is $299-\mathrm{W} 15-37$, located $\sim 100 \mathrm{~m} \mathrm{(330} \mathrm{ft)} \mathrm{northwest}$ of the WMA (see Figure 3.4). After removal of carbon tetrachloride, the water is reinjected into the aquifer in several wells immediately west of the 200 West Area boundary. As a result of the pump-andtreat activities, groundwater at the WMA may flow more toward the northeast direction some time in the future. This condition may represent relative stability, as there are no plans to halt the pump-and-treat operations in the foreseeable future. However, there is also a chance that changing flow directions, and potential injection of contaminants upgradient to the WMA, may result in changes in upgradient contaminant chemistry. 


\subsection{Evaluation of Specific Conductance Data}

The general contamination indicator data were statistically evaluated by comparing concentrations obtained from downgradient wells with those obtained from upgradient wells. One of the indicator parameters, specific conductance, exceeded its background values in one downgradient well, 299-W1941 , during the fourth quarter of fiscal year 1999 sampling. The elevation of specific conductance triggers a shift from detection monitoring to a groundwater assessment program. A general description of the statistical method is presented first. Evaluation of the specific conductance data is presented next.

\subsection{Statistical Evaluation Method}

The goal of RCRA detection monitoring is to determine if WMA $U$ has affected groundwater quality. This is determined based on the results of a statistical test. According to 40 CFR 265.92 (and by reference in WAC 173-303-400[3]), the owner/operator of an interim-status hazardous waste facility must establish initial background concentrations for the contamination indicator parameters: specific conductance, $\mathrm{pH}, \mathrm{TOC}$, and TOX. This has been done for WMA U by obtaining at least four replicate measurements for each parameter from each well quarterly for 1 year. Data from the upgradient well(s) were used to determine the initial background arithmetic mean and variance.

Monitoring data collected after the first year are compared with the initial background data to determine if there is an indication that contamination may have occurred. A t-test is required to make this determination (40 CFR 265.93[b]). A recommended method is the averaged replicate t-test method described in Appendix B of the RCRA Groundwater Monitoring Technical Enforcement Guidance Document (EPA 1986ba). The averaged replicate t-test method for each contamination indicator parameter is calculated as follows:

$$
\mathrm{t}=\left(\overline{\mathrm{x}}_{\mathrm{i}}-\overline{\mathrm{x}}_{\mathrm{b}}\right) / \mathrm{S}_{\mathrm{b}} * \sqrt{1+1 / \mathrm{n}_{\mathrm{b}}}
$$

where $\mathrm{t}=$ test statistic

$\bar{x}_{i}=$ average of replicates from the ith monitoring well

$\overline{\mathrm{x}}_{\mathrm{b}}=$ background average

$\mathrm{S}_{\mathrm{b}}=$ background standard deviation

$\mathrm{n}_{\mathrm{b}}=$ number of background replicate averages.

A test statistic larger than the Bonferroni critical value, $t_{c}$ (i.e., $t>t_{c}$ ), indicates a statistically significant probability of contamination. These Bonferroni critical values depend on the overall falsepositive rate required for each sampling period (i.e., $1 \%$ for interim status), the total number of wells in the monitoring network, and the number of degrees of freedom $\left(n_{b}-1\right)$ associated with the background standard deviation. Because of the nature of the test statistic in the above equation, results to be compared to background do not contribute to the estimate of the variance. The test can be reformulated, without prior knowledge of the results of the sample to be compared to background (i.e., $\bar{x}_{i}$ ), in such a way that a critical mean, CM, can be obtained: 


$$
\begin{aligned}
& C M=\bar{x}_{b}+t_{c} * S_{b} * \sqrt{\left(1+1 / n_{b}\right)} \quad \text { (one tailed) } \\
& C M=\bar{x}_{b} \pm t_{c} * S_{b} * \sqrt{\left(1+1 / n_{b}\right)} \quad \text { (two tailed) }
\end{aligned}
$$

If downgradient data exceed the critical means, they are determined to be statistically different from background. For $\mathrm{pH}$, a two-tailed critical mean (or critical range) is calculated, and downgradient data beyond the range are considered to be statistically different from background. If a statistical exceedance is detected, the well will be resampled to determine if the originally detected increase (or $\mathrm{pH}$ decrease) was a result of laboratory or measurement error (verification sampling). If verification sampling confirms the exceedance, the owner/operator must notify Ecology within 7 days and submit a groundwater quality assessment plan within 15 days following the notification (40 CFR 265.93[d]). The goal of the assessment monitoring program is to determine if dangerous waste or dangerous waste constituents from the facility have entered the groundwater and, if so, to determine their concentration and the rate and extent of migration in groundwater (40 CFR 265.93[d]).

\subsection{Evaluation of Specific Conductance Data}

Groundwater flow directions at WMA $U$ have been in constant flux since the initiation of RCRA groundwater monitoring as a result of changing effluent discharge patterns within the 200 West Area (see Section 3.2). Changes in site conditions (e.g., reversal of flow direction, discharge practice) have necessitated the revision of background values (critical means) to be used in the statistical evaluation. Specific conductance data from the WMA U monitoring wells is presented in Figure 4.1. Wells 299-W18-25 and 299-W18-31 were the upgradient wells when groundwater monitoring was first initiated at WMA U (October 1991). Original background values were established using quarterly monitoring data collected from April 1992 to March 1993 (Table 4.1). The critical mean for specific conductance was $407 \mu \mathrm{S} / \mathrm{cm}$.

In the 1991-1993 time period, two major effluent discharges to the 216-U-14 ditch, southeast of WMA U, resulted in a temporary reversal of flow directions at WMA U. From early 1993 until 1995, upgradient wells 299-W18-25 and 299-W18-31 became downgradient wells, resuming their upgradient identities in 1996 as groundwater flow swung back around toward the east (see Section 3.2). Because of the changes in groundwater flow direction, background values were recalculated in 1996. The results are presented in Table 4.2. The average specific conductance concentration was increased from $\sim 240 \pm$ $29 \mu \mathrm{S} / \mathrm{cm}$ (see Table 4.1) to $\sim 309 \pm 39 \mu \mathrm{S} / \mathrm{cm}$ (see Table 4.2). As a result, the critical mean was increased from $\sim 407$ to $\sim 533 \mu \mathrm{S} / \mathrm{cm}$.

Since the 1996 revision, specific conductance from upgradient wells 299-W18-25 and 299-W18-31 showed lower but steady concentrations (see Figure 4.1). Background concentrations were recalculated in fiscal year 1999 and are presented in Table 4.3. The combination of lower average specific conductance values, together with a much smaller variation in the upgradient wells, resulted in a near $50 \%$ reduction in the critical mean value (from $\sim 533$ to $\sim 273 \mu \mathrm{S} / \mathrm{cm}$; see Figure 4.1 ). 

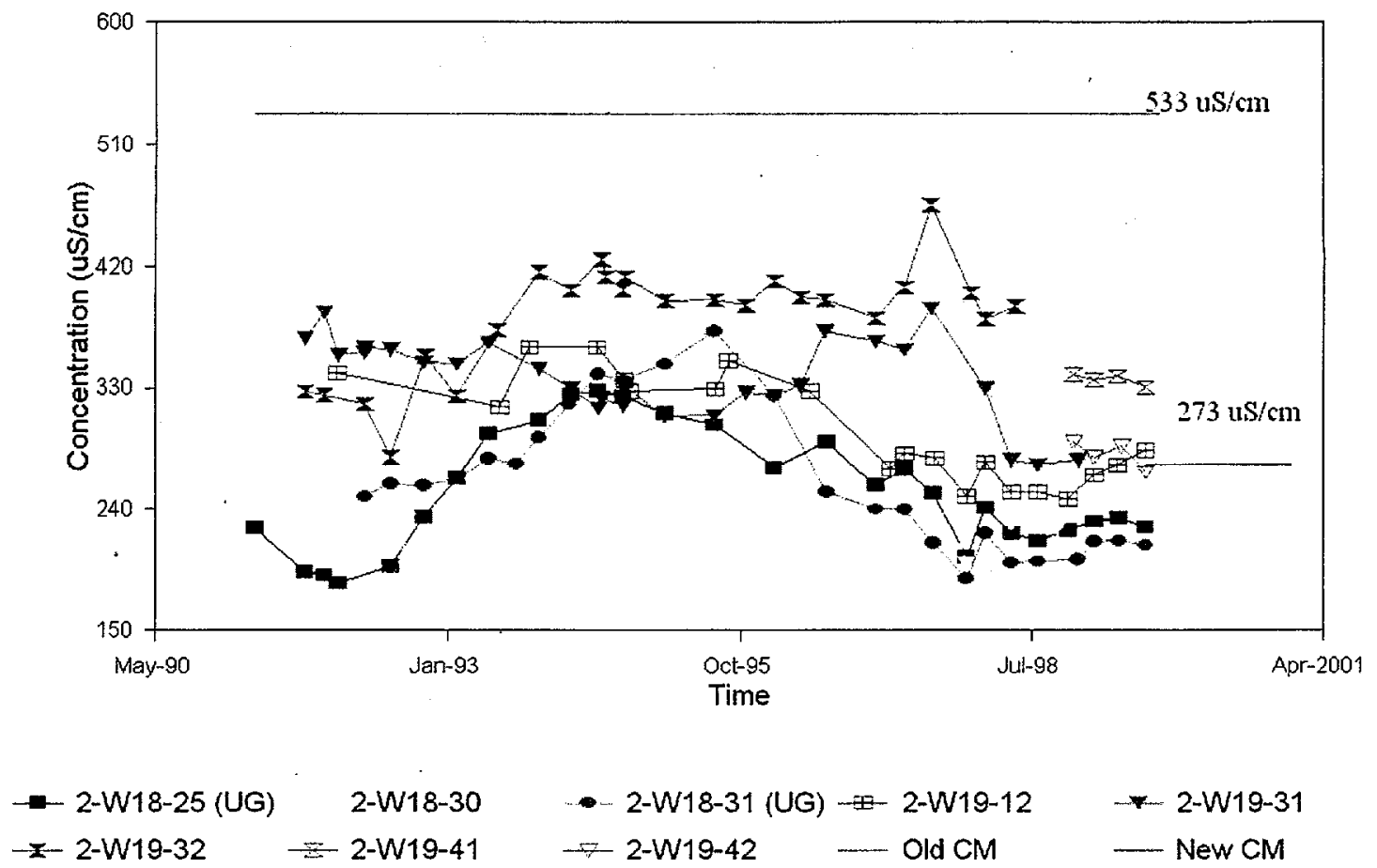

Figure 4.1. Specific Conductance Concentration Versus Time at Monitoring Wells for Waste Management Area U

Table 4.1. ${ }^{\text {(a) }}$ Critical Means for 20 Comparisons--Background Contamination Indicator Parameter Data for Waste Management Area $U^{(b)}$

\begin{tabular}{|c|c|c|c|c|c|c|c|}
\hline Constituent, unit & $\mathrm{n}$ & $\mathrm{df}$ & $\mathrm{t}_{\mathrm{c}}$ & $\begin{array}{c}\text { Average } \\
\text { Background }\end{array}$ & $\begin{array}{l}\text { Standard } \\
\text { Deviation }\end{array}$ & $\begin{array}{l}\text { Critical } \\
\text { Mean }\end{array}$ & $\begin{array}{c}\text { Upgradient/ } \\
\text { Downgradient } \\
\text { Comparison Value }\end{array}$ \\
\hline $\begin{array}{l}\text { Specific conductance, } \\
\mu \mathrm{S} / \mathrm{cm}\end{array}$ & 8 & 7 & 5.4079 & 239.562 & 29.216 & 407.1 & 407.1 \\
\hline Field $\mathrm{pH}$ & $7^{\text {(c) }}$ & 6 & 6.7883 & 7.909 & 0.328 & {$[5.53 ; 10.29]$} & {$[5.53,10.29]$} \\
\hline Total organic carbon, ${ }^{(d)} \mu \mathrm{g} / \mathrm{L}$ & $7^{(\mathrm{c})}$ & 6 & 5.9588 & 500 & $\mathrm{NC}$ & $\mathrm{NC}$ & 800 \\
\hline $\begin{array}{l}\text { Total organic halides, }{ }^{(\mathrm{e})} \\
\mu \mathrm{g} / \mathrm{L}\end{array}$ & NC & $\mathrm{NC}$ & NC & NC & NC & NC & $\mathrm{NC}$ \\
\hline $\begin{array}{l}\text { (a) Source: Caggiano (1994 } \\
\text { (b) Data collected from Apri } \\
\text { (c) Excluding outliers. } \\
\text { (d) Upgradient/downgradien } \\
\text { (e) Critical mean cannot be } \\
\text { df }=\text { Degrees of freedom } \\
\mathrm{n}=\text { Number of backgrou } \\
\mathrm{t}_{\mathrm{c}}=\text { Bonferroni critical t- } \\
\mathrm{NC}=\text { Not calculated. }\end{array}$ & $\begin{array}{l}\text { com } \\
\text { alcul } \\
\text { (n-1). } \\
\text { nd re } \\
\text { value }\end{array}$ & $\begin{array}{l}\text { paris } \\
\text { ated } 1\end{array}$ & $\begin{array}{l}\text { Aarch } 19 \\
\text { on value } \\
\text { pecause } \\
\text { e averag } \\
\text { ppropria }\end{array}$ & $\begin{array}{l}\text { is the limit of } \\
\text { f problems as } \\
\text { es. }\end{array}$ & $\begin{array}{l}\text { uantitation } \\
\text { ociated with } \\
\text { nparisons. }\end{array}$ & $\begin{array}{l}\text { W18-25 and } 2 \\
\text { ased on } 1993 \mathrm{f} \\
\text { lata quality. }\end{array}$ & 9-W18-31. \\
\hline
\end{tabular}


Table 4.2. ${ }^{\text {(a) }}$ Critical Means for 20 Comparisons--Background Contamination Indicator Parameter Data for Waste Management Area $U^{(b)}$

\begin{tabular}{|c|c|c|c|c|c|c|c|}
\hline Constituent, unit & $\mathbf{n}$ & $\mathrm{df}$ & $t_{c}$ & $\begin{array}{c}\text { Average } \\
\text { Background }\end{array}$ & $\begin{array}{c}\text { Standard } \\
\text { Deviation } \\
\end{array}$ & $\begin{array}{l}\text { Critical } \\
\text { Mean } \\
\end{array}$ & $\begin{array}{c}\text { Upgradient/ } \\
\text { Downgradient } \\
\text { Comparison Value }\end{array}$ \\
\hline $\begin{array}{l}\text { Specific conductance, } \\
\mu \mathrm{S} / \mathrm{cm}\end{array}$ & 8 & 7 & 5.4079 & 308.875 & 39.032 & 532.8 & 532.8 \\
\hline Field $\mathrm{pH}$ & 8 & 7 & 6.0818 & 8.008 & 0.091 & $\begin{array}{l}{[7.42,} \\
8.59]\end{array}$ & {$[7.42,8.59]$} \\
\hline $\begin{array}{l}\text { Total organic carbon, }{ }^{(\mathrm{c})} \\
\mu \mathrm{g} / \mathrm{L}\end{array}$ & 8 & 7 & 5.4079 & 275.031 & 82.580 & 748.7 & 1,140 \\
\hline $\begin{array}{l}\text { Total organic halides, } \\
\mu \mathrm{g} / \mathrm{L}\end{array}$ & 8 & 7 & 5.4079 & 102.994 & 24.120 & 241.3 & 241.3 \\
\hline \multicolumn{8}{|c|}{$\begin{array}{l}\text { a) Source: Hartman (1999), Table B.20. } \\
\text { (b) Data collected based on semiannual sampling events from February } 1995 \text { to August } 1996 \text { for } \\
\text { upgradient wells } 299-W 18-25 \text { and } 299-W 18-31 \text {. } \\
\text { (c) Upgradient/downgradient comparison value is the limit of quantitation. } \\
\text { df }=\text { Degrees of freedom (n-1). } \\
\mathrm{n}=\text { Number of background replicate averages. } \\
\mathrm{t}_{\mathrm{c}}=\text { Bonferroni critical t-value for appropriate df and } 20 \text { comparisons. }\end{array}$} \\
\hline
\end{tabular}

Table 4.3. Critical Means for 20 Comparisons--Background Contamination Indicator Parameter Data for Waste Management Area $\mathrm{U}^{(\mathrm{a})}$

\begin{tabular}{|c|c|c|c|c|c|c|c|}
\hline Constituent, unit & $\mathrm{n}$ & $\mathrm{df}$ & $t_{c}$ & $\begin{array}{c}\text { Average } \\
\text { Background }\end{array}$ & $\begin{array}{l}\text { Standard } \\
\text { Deviation }\end{array}$ & $\begin{array}{c}\text { Critical } \\
\text { Mean }\end{array}$ & $\begin{array}{c}\text { Upgradient/ } \\
\text { Downgradient } \\
\text { Comparison Value }\end{array}$ \\
\hline $\begin{array}{l}\text { Specific conductance, } \\
\mu \mathrm{S} / \mathrm{cm}\end{array}$ & 10 & 9 & 4.7815 & 218.175 & 10.870 & 272.7 & 272.7 \\
\hline Field $\mathrm{pH}$ & 10 & 9 & 5.2912 & 8.088 & 0.112 & $\begin{array}{l}{[7.46,} \\
8.71]\end{array}$ & {$[7.46,8.71]$} \\
\hline $\begin{array}{l}\text { Total organic carbon, }{ }^{(6)} \\
\mu \mathrm{g} / \mathrm{L}\end{array}$ & 10 & 9 & 4.7815 & 465.250 & 125.069 & $1,092.5$ & $1,153.7$ \\
\hline Total organic halides, $\mu \mathrm{g} / \mathrm{L}$ & 10 & 9 & 4.7815 & 32.938 & 25.438 & 160.5 & 160.5 \\
\hline 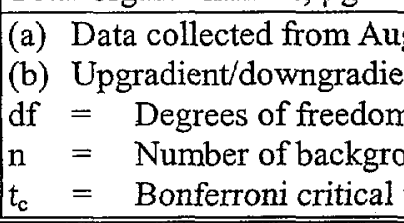 & $\begin{array}{l}\text { yust } 1 \\
\text { at cor } \\
\text { (n-1) } \\
\text { und } \mathrm{r} \\
\text {-valu }\end{array}$ & $\begin{array}{l}1998 \\
\text { mpar } \\
\text {. } \\
\text { replic } \\
\text { ue for }\end{array}$ & $\begin{array}{l}8 \text { to Aug } \\
\text { irison ve } \\
\text { icate av } \\
\text { or appro }\end{array}$ & $\begin{array}{l}\text { ust } 1999 \text { for uy } \\
\text { lue is the limit } \\
\text { rages. } \\
\text { priate df and } 2\end{array}$ & quantita & $\overline{99-W 18}$ & and 299-W18-31. \\
\hline
\end{tabular}


The clearest link between specific conductance and groundwater chemistry is through the equivalents of dissolved ionic solids present in the groundwater. The major element chemistries of recent groundwater samples from WMA U, in terms of milliequivalents, are presented in Table 4.4. All major components, with the exception of potassium, are higher in well 299-W19-41 than in the downgradient wells; however, the major contributors to the higher specific conductance are naturally occurring constituents: chloride, sulfate, calcium, and magnesium. Nitrate, chromium, and technetium-99 are increasing in well 299-W19-41; however, they are well below their respective drinking water standards. If nitrate were completely removed, groundwater in this well would still exceed the critical mean for specific conductance. 
Table 4.4. Milliequivalents in Recent Waste Management Area U Groundwater Samples

\begin{tabular}{|c|c|c|c|c|c|c|c|}
\hline Well & 299-W19-41 & 299-W 19-41 & 299-W19-32 & 299-W 19-42 & 299-W18-30 & 299-W18-25. & 299-W18-31 \\
\hline Date & $8 / 17 / 99$ & $1 / 26 / 00$ & $5 / 28 / 98^{(\mathrm{a})}$ & $8 / 17 / 99$ & $10 / 7 / 99$ & $8 / 18 / 99$ & $8 / 17 / 99$ \\
\hline \multicolumn{8}{|c|}{ Cations (meq) } \\
\hline Sodium & $0.88(24.9 \%)^{(b)}$ & $0.83(24.5 \%)$ & $0.91(22.8 \%)$ & $0.81(27.5 \%)$ & $0.80(30.1 \%)$ & $0.66(27.0 \%)$ & $0.60(26.1 \%)$ \\
\hline Potassium & $0.12(3.3 \%)$ & $0.10(2.9 \%)$ & $0.13(3.3 \%)$ & $0.08(2.7 \%)$ & $0.10(3.8 \%)$ & $0.07(2.9 \%)$ & $0.11(4.8 \%)$ \\
\hline Calcium & $1.64(46.5 \%)$ & $1.59(47.1 \%)$ & $2.00(50.0 \%)$ & $1.33(45.1 \%)$ & $1.16(62.4 \%)$ & $1.09(44.7 \%)$ & $1.03(44.8 \%)$ \\
\hline Magnesium & $0.89(25.2 \%)$ & $0.86(25.5 \%)$ & $0.96(24.0 \%)$ & $0.73(24.7 \%)$ & $0.60(25.4 \%)$ & $0.62(25.4 \%)$ & $0.56(24.3 \%)$ \\
\hline Sum & 3.53 & 3.37 & 4.00 & 2.95 & 2.66 & 2.44 & 2.30 \\
\hline \multicolumn{8}{|c|}{ Anions (meq) } \\
\hline Chloride & $0.40(12.3 \%)$ & $0.45(12.3 \%)$ & $0.83(22.0 \%)$ & $0.20(7.5 \%)$ & $0.17(6.3 \%)$ & $0.16(6.6 \%)$ & $0.11(5.0 \%)$ \\
\hline Sulfate & $0.59(18.1 \%)$ & $0.71(19.5 \%)$ & $0.71(18.8 \%)$ & $0.44(16.4 \%)$ & $0.43(15.8 \%)$ & $0.40(16.5 \%)$ & $0.33(15.1 \%)$ \\
\hline Alkalinity & $2.04(62.6 \%)$ & $2.18(60.0 \%)$ & $2.20(58.4 \%)$ & $1.80(67.2 \%)$ & $1.92(70.6 \%)$ & $1.76(78.7 \%)$ & $1.70(77.6 \%)$ \\
\hline Nitrate & $0.23(7.0 \%)$ & $0.30(8.2 \%)$ & $0.03(0.8 \%)$ & $0.24(9.0 \%)$ & $0.20(7.4 \%)$ & $0.10(4.1 \%)$ & $0.05(2.3 \%)$ \\
\hline Sum & 3.26 & 3.63 & 3.77 & 2.68 & 2.72 & 2.42 & 2.19 \\
\hline $\begin{array}{l}\text { Specific } \\
\text { Conductance }\end{array}$ & $331 \mu \mathrm{S} / \mathrm{cm}$ & $\begin{array}{l}355 \mu \mathrm{S} / \mathrm{cm}^{(\mathrm{c})} \\
343 \mu \mathrm{S} / \mathrm{cm}^{(\mathrm{d})}\end{array}$ & $390 \mu \mathrm{S} / \mathrm{cm}$ & $270 \mu \mathrm{S} / \mathrm{cm}$ & $269 \mu \mathrm{S} / \mathrm{cm}$ & $227 \mu \mathrm{S} / \mathrm{cm}$ & $214 \mu \mathrm{S} / \mathrm{cm}$ \\
\hline \multicolumn{8}{|c|}{$\begin{array}{l}\text { (a) Last available sample from well. } \\
\text { (b) Percentage of total cations or anions. } \\
\text { (c) Field measurement. } \\
\text { (d) Laboratory measurement. }\end{array}$} \\
\hline
\end{tabular}




\subsection{Groundwater Quality Assessment Program}

The monitoring program was set up to meet the requirements of RCRA regulations (40 CFR 265, Subpart F). The overriding objective of the RCRA regulations is the protection of human health and the environment. The protection of human health and the environment under RCRA is accomplished through monitoring for releases of hazardous chemicals to the environment, in this case groundwater, and carrying out the appropriate assessment and possible corrective actions if a release of contaminants has been determined to exist.

\subsection{Summary of Approach}

As discussed in Section 4.2, the average result of quadruplicate samples from downgradient well 299-W19-41 exceeded the recalculated critical mean for specific conductance. There has been a significant decrease $(\sim 50 \%)$ in the critical mean for WMA $U$ as a result of lower average background concentrations and a lower degree of variability in recent samplings. The higher specific conductance observed in well 299-W19-41 is a result of nonhazardous constituents (sodium, calcium, magnesium, chloride, sulfate, and bicarbonate). However, nitrate, chromium, and technetium-99 are increasing in well 299-W19-41. Therefore, the objective of the first phase of the assessment program is to determine, as allowed under 40 CFR 265.93(d)(5), whether the increasing concentrations of nitrate and chromium are originating from the WMA or an upgradient source. The approach includes the following steps:

- review waste site information for potential contaminant sources

- evaluate existing and future water-level data from WMA U monitoring wells and other wells in the 200 West Area to assess the groundwater flow directions

- evaluate chemistry data from WMA U monitoring wells

- develop a conceptual model of hypothetical sources, constituents of interest, driving forces, and pathway to groundwater

- evaluate monitoring network to identify data gaps.

Based on the results of the first determination, if WMA U is not the source of groundwater contamination, then the site will revert to detection monitoring. If WMA $U$ is the source, then a second part of the groundwater quality assessment plan will be prepared to define the rate and extent of migration of contaminants in the groundwater and their concentrations, as required under 40 CFR 265.93(d)(4). 


\subsection{Special Conditions at WMA U}

Groundwater flow directions at WMA $U$ have been in constant flux since the initiation of RCRA groundwater monitoring as a result of changing effluent discharge patterns within the 200 West Area (see Section 3.2). More recently, the 200-ZP-1 Operable Unit pump-and-treat operations have influenced groundwater flow directions at the WMA. Prior to the reversal in groundwater flow direction, resulting from discharge to the 216-U-14 ditch, groundwater flow was toward the southeast. As the effects of the discharge waned, groundwater flow began to swing around to a west-to-east orientation; however, groundwater at the WMA may flow more toward the northeast direction sometime in the future. The southern-

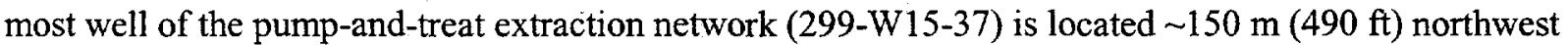
of the WMA. WMA $U$ is apparently just outside of the capture zone of well 299-W15-37; however, it is near enough to impose a northerly component on groundwater flow direction at the WMA, particularly in the northern part (see Figure 3.4). The adequacy of the monitoring network will be reevaluated.

\subsection{Sampling and Analysis Program}

\subsubsection{Monitoring Well Network}

The current groundwater monitoring network at WMA U consists of five RCRA-compliant wells and one pre-RCRA well used for information only (Table 5.1). Two of the wells (299-W18-25 and 299-W18-31) are upgradient wells. Three RCRA-compliant wells (299-W18-30, 299-W19-41, and 299-W19-42) as well as pre-RCRA well 299-W19-12 are downgradient. The construction drawings or as-built diagrams for wells listed in Table 5.1 are presented in the Appendix.

Three of the original RCRA wells were constructed prior to Ecology approval of the 10.7-m (35-ft) screened intervals and were completed with $4.6-\mathrm{m}(15-\mathrm{ft})$ screened intervals. The last two of the original five RCRA wells, drilled in 1991, were completed with 10.7-m (35-ft) screened intervals. Subsequently, two of the original RCRA wells (299-W19-31 and 299-W19-32) cannot be sampled because of the decline in the water table. Also, upgradient well 299-W18-25 is expected to go dry in early 2000.

Two replacement wells were drilled in 1998. Well 299-W19-42 was drilled as a replacement for downgradient well 299-W19-31 and well 299-W19-41 was drilled as a replacement for downgradient well 299-W19-32. Both wells 299-W19-41 and 299-W19-42 were completed with 10.7-m (35-ft) screened intervals to extend the operational lives of the wells. Upgradient well 299-W18-25 will probably become unsampleable in early calendar year 2000; however, upgradient well 299-W18-31 should be able to be sampled until at least 2004. There are no immediate plans to replace well 299-W18-25. 
Table 5.1. Wells in Monitoring Network

\begin{tabular}{|c|c|c|c|c|c|}
\hline Well & $\begin{array}{l}\text { Depth to } \\
\text { Bottom of } \\
\text { Borehole } \\
\text { (m) }\end{array}$ & $\begin{array}{l}\text { Depth to } \\
\text { Water } \\
\text { (m) }\end{array}$ & $\begin{array}{l}\text { Screen Length } \\
\text { (m) }\end{array}$ & $\begin{array}{l}\text { Construction } \\
\text { Casing/Screen }\end{array}$ & Monitoring Interval \\
\hline $299-\mathrm{W} 18-25^{90}$ & 65.7 & 65.7 & 4.6 & $\mathrm{SS} / \mathrm{SS}^{(\mathrm{a})}$ & Top of unconfined \\
\hline $299-\mathrm{W} 18-30^{91}$ & 71.8 & 68.2 & 10.7 & SS/SS & Top of unconfined \\
\hline $299-W 18-31^{91}$ & 69.4 & 65.2 & 10.7 & SS/SS & Top of unconfined \\
\hline $299-W 19-12^{83(b)}$ & 76.2 & 68.2 & 12.2 & $\mathrm{CS}^{(\mathrm{c})} / \mathrm{SS}(?)$ & Top of unconfined \\
\hline $299-W 19-31^{90(d)}$ & 68.7 & 68.6 & 4.6 & SS/SS & Dry \\
\hline $299-W 19-32^{91(d)}$ & 68.0 & 68.8 & 4.6 & SS/SS & Dry \\
\hline $299-W 19-41^{98}$ & 80.6 & 68.5 & 10.7 & SS/SS & Top of unconfined \\
\hline $299-W 19-42^{98}$ & 80.8 & 68.3 & 10.7 & SS/SS & Top of unconfined \\
\hline \multicolumn{6}{|c|}{$\begin{array}{l}\text { Note: Superscript following well number denotes year of installation. } \\
\text { (a) Stainless steel. } \\
\text { (b) Pre-RCRA. } \\
\text { (c) Carbon steel. } \\
\text { (d) Unsampleable. }\end{array}$} \\
\hline
\end{tabular}

Pre-RCRA well 299-W19-12 is sampled to fill a gap in the downgradient network and to provide continuity with pre-RCRA monitoring. Because of uncertainties about the construction, well 299-W19-12 is currently used for indication only, and indicator parameters for this well were not included in statistical analysis for WMA U.

\subsubsection{Constituent List and Sampling Frequency}

The groundwater at WMA U will continue to be sampled on a quarterly schedule for the key tank waste constituents and/or indicators. The more frequent sampling is required under a groundwater quality assessment program. The sampling constituent list is presented in Table 5.2. The constituent list and/or sample frequency shown in Table 5.2 may be revised as more information becomes available.

TOX has been dropped from the list of RCRA indicator parameters measured at WMA U. Although tank waste at WMA $U$ contains organic constituents, most of these are complexants used during processing, and chlorinated hydrocarbons are insignificant. In addition, encroachment of the Plutonium Finishing Plant carbon tetrachloride plume has resulted in a number of TOX exceedances that were unrelated to WMA U. Carbon tetrachloride will be monitored on an annual basis to allow an evaluation of this important groundwater contaminant in the vicinity of the WMA. 
Table 5.2. Constituent List

\begin{tabular}{|c|c|c||}
\hline \multicolumn{3}{|c||}{ Contamination Indicator Parameters } \\
\hline Specific conductance & Total organic carbon & $\mathrm{pH}$ \\
\hline \multicolumn{3}{|c||}{ Groundwater Quality Parameters } \\
\hline Chloride & Manganese & Sodium \\
\hline Iron & Phenols $^{\text {(a) }}$ & Sulfate \\
\hline \multicolumn{3}{|c||}{ Site-Specific Constituents } \\
\hline Chromium & Gross alpha & Technetium-99 \\
\hline Nitrate & Gross beta & Tritium \\
\hline Cobalt-60 & Iodine-129 & \\
\hline \multicolumn{2}{|c||}{ Other Constituents } \\
\hline $\begin{array}{l}\text { Carbon Tetrachloride } \\
\text { (a) Not analyzed. } \\
\text { (b) Annually. }\end{array}$
\end{tabular}

The groundwater quality parameters, with the exception of phenols, will be analyzed on a quarterly basis. Phenols, which are not constituents of tank waste, will be not be analyzed.

Chromium, nitrate, technetium-99, cobalt-60 (from gamma scan), iodine-129, and tritium will be analyzed quarterly because they are significant mobile constituents of tank waste. Technetium-99, cobalt-60, iodine-129, and tritium (non-RCRA co-contaminants) will be used as tracers. Gross alpha and gross beta will be analyzed quarterly as screening tools for other potential radionuclide contamination. If reported gross alpha exceeds the expected alpha activity as a result of the presence of uranium, transuranics analyses will be requested. Likewise, if the reported gross beta exceeds the expected gross beta level based on the technetium-99 present, more specific isotopic analyses will be requested (e.g., strontium-90).

\subsubsection{Determination of Groundwater Flow Directions}

Water levels will be measured in monitoring wells at the time of sampling and additional wells in the 200 West Area may be measured independently to provide a firmer basis for determination of groundwater flow directions. Water-table elevations will be used to determine groundwater flow directions at the site. Results of these determinations will be discussed in the annual Hanford Site Groundwater Monitoring Report and in the groundwater quality assessment report.

\subsubsection{Sampling and Analysis Protocol}

Monitoring for WMA U is part of the Hanford Groundwater Monitoring Project. Procedures for groundwater sampling, documentation, sample preservation, shipment, and chain-of-custody 
requirements are described in Pacific Northwest National Laboratory or subcontractor manuals (e.g., currently Waste Management Federal Services, Inc., Northwest Operations' procedures manual ES-SSPM-001) and in the quality assurance plan (PNNL 1998). Samples generally are collected after three casing volumes of water have been purged from the well or after field parameters ( $\mathrm{pH}$, temperature, and specific conductance) have stabilized, and turbidity is 25 NTU or less. For routine groundwater samples, preservatives are added to the collection bottles before their use in the field. Samples to be analyzed for metals are usually filtered in the field so that results represent dissolved metals.

Procedures for field measurements are specified in the subcontractor's or manufacturer's manuals. Analytical methods are specified in contracts with laboratories, and most are standard methods from Test Methods for Evaluating Solid Wastes: Physical/Chemical Methods (EPA 1986b). Alternative procedures meet the guidelines of SW-846, Chapter 10 (EPA 1986b). Analytical methods are described in Gillespie (1999).

\subsubsection{Data Evaluation}

The primary mobile constituents associated with a tank or related source should co-vary in groundwater at a specific well or wells if a WMA source is responsible for the observed change in groundwater quality by comparing the concentrations in relation to background concentrations. Accordingly, the quarterly results for technetium-99, chromate, and nitrate for the upgradient well and downgradient wells monitoring the $U$ Tank Farm will be plotted to identify any abrupt changes or trends. Interpretive techniques include hydrographs, water-table maps, trend plots, plume maps, and contaminant ratios (Section 6.2).

\subsubsection{Quality Assurance and Quality Control}

The Hanford Groundwater Monitoring Project's quality assurance/quality control program is designed to assess and enhance the reliability and validity of groundwater data. The primary quantitative measures or parameters used to assess data quality are accuracy, precision, completeness, and method detection limit. Qualitative measures include representativeness and comparability. Goals for data representativeness for groundwater monitoring projects are addressed qualitatively by the specification of well locations, well construction, sampling intervals, and sampling and analysis techniques in the groundwater monitoring plan for each RCRA facility. Comparability is the confidence with which one data set can be compared to another. The quality control parameters are evaluated through laboratory checks (e.g., matrix spikes, laboratory blanks), replicate sampling and analysis, analysis of blind standards and blanks, and interlaboratory comparisons. Acceptance criteria have been established for each of these parameters (PNNL 1998), based on guidance from the U.S. Environmental Protection Agency (OSWER-9950.1, EPA 1986a). When a parameter is outside the criteria, corrective actions are taken to prevent a future occurrence and affected data are flagged in the database.

\subsubsection{Schedule of Implementation}

Monitoring wells in the existing network will be sampled quarterly (February, May, August, and November) for the constituents specified in Table 5.1, with the exception of carbon tetrachloride that will 
be sampled semiannually for tracking the movement of the plume originated from the Plutonium Finishing Plant. Specific isotopic analyses will be requested if reported elevated gross alpha or gross beta values exceed the expected activity as a result of the presence of uranium or technetium- 99 , respectively. Results of the sampling and analysis for WMA U will be submitted to the U.S. Department of Energy and Ecology in the form of quarterly status reports (April, July, October, January) and groundwater annual reports (March). Results of the first determination will be due to the U.S. Department of Energy on September 30, 2000 and to Ecology shortly thereafter. 


\subsection{Data Management, Evaluation, and Reporting}

This chapter describes how groundwater data are stored, retrieved, evaluated, and interpreted. Reporting requirements are also described.

\subsection{Data Management}

The contract laboratories report analytical results electronically. The results are loaded into the Hanford Environmental Information System (HEIS) database. Field-measured parameters are entered manually or through electronic transfer. Data from HEIS may be downloaded to smaller databases, such as the Geosciences Data Analysis Toolkit (GeoDAT) for data validation, reduction, and trend analysis. Paper data reports and field records are considered to be the record copies and are stored at Pacific Northwest National Laboratory.

The data undergo a validation/verification process according to a documented procedure, as indicated in the project quality assurance plan. Quality control data are evaluated against the criteria listed in the project quality assurance plan, and data flags are assigned when appropriate. In addition, data are screened by scientists familiar with the hydrogeology of the unit, compared to historical trends or spatial patterns, and flagged if they are not representative. Other checks on data may include comparison of general parameters to their specific counterparts (e.g., conductivity to ions; gross alpha to uranium), calculation of charge balances, and comparison of calculated versus measured conductance. If necessary, the laboratory may be asked to check calculations or reanalyze the sample, or the well may be resampled.

\subsection{Interpretation}

After data are validated and verified, the acceptable data are used to interpret groundwater conditions at the site. Interpretive techniques include the following:

- Hydrographs: graph water levels versus time to determine decreases, increases, seasonal, or manmade fluctuations in groundwater levels.

- Water-table maps: use water-table elevations from multiple wells to construct contour maps to estimate flow directions. Groundwater flow is assumed to be perpendicular to lines of equal potential.

- Trend plots: graph concentrations of chemical or radiological constituents versus time to determine increases, decreases, and fluctuations. May be used in tandem with hydrographs and/or water-table maps to determine if concentrations relate to changes in water level or in groundwater flow directions. 
- Plume maps: map distributions of chemical or radiological constituents in the aquifer to determine extent of contamination. Changes in plume distribution over time aid in determining movement of plumes and direction of flow.

- Contaminant ratios: sometimes used to distinguish between different sources of contamination.

\subsection{Reporting}

Chemistry and water-level data are reviewed at least quarterly and are available in HEIS. Interpretive reports are issued annually in March (e.g., Hartman 1999). Reporting requirements are listed in Table 6.1.

Table 6.1. Reports Required for Compliance with 40 CFR 265, Subpart F, for Groundwater Monitoring

\begin{tabular}{|c|c|c|c|}
\hline Submittal & Submittal Period & $\begin{array}{l}\text { Reporting Vehicle } \\
\text { (applicable date) }\end{array}$ & $\begin{array}{c}\text { Regulatory } \\
\text { Requirement }\end{array}$ \\
\hline $\begin{array}{l}\text { First year of sampling: concentrations } \\
\text { of interim primary drinking water } \\
\text { constituents, identifying those that } \\
\text { exceed limits }\end{array}$ & Quarterly & $\begin{array}{l}\text { Complete }^{(a)} \\
(4 / 92-3 / 93)\end{array}$ & $\begin{array}{l}40 \text { CFR } \\
265.94(a)(2)(i)\end{array}$ \\
\hline $\begin{array}{l}\text { Concentration and statistical analyses } \\
\text { of groundwater contamination indica- } \\
\text { tor parameters, noting significant } \\
\text { differences in upgradient wells }\end{array}$ & $\begin{array}{l}\text { Annually, by March } \\
1 \text { of following year }\end{array}$ & $\begin{array}{l}\text { Annual Hanford } \\
\text { Groundwater } \\
\text { Monitoring Report } \\
\text { (e.g., Hartman 1999) }\end{array}$ & $\begin{array}{l}40 \mathrm{CFR} \\
265.94(\mathrm{a})(2)(\mathrm{ii})\end{array}$ \\
\hline $\begin{array}{l}\text { Results of groundwater surface eleva- } \\
\text { tion evaluation and description of } \\
\text { response if appropriate }\end{array}$ & $\begin{array}{l}\text { Annually, by March } \\
1 \text { of following year }\end{array}$ & $\begin{array}{l}\text { Annual Hanford } \\
\text { Groundwater } \\
\text { Monitoring Report }\end{array}$ & $\begin{array}{l}40 \mathrm{CFR} \\
265.94(\mathrm{a})(2)(\mathrm{iii})\end{array}$ \\
\hline Notification of statistical exceedance ${ }^{(b)}$ & $\begin{array}{l}\text { Within } 7 \text { days of } \\
\text { verification }\end{array}$ & $\begin{array}{l}\text { Letter to Ecology } \\
(2 / 14 / 2000)\end{array}$ & 40 CFR 265.93(c) \\
\hline Assessment plan ${ }^{(\mathrm{b})}$ & $\begin{array}{l}\text { Within } 15 \text { days of } \\
\text { notification }\end{array}$ & $\begin{array}{l}\text { PNNL document } \\
(2 / 28 / 2000)\end{array}$ & 40 CFR 265.93(d) \\
\hline $\begin{array}{l}\text { First determinations under assessment } \\
\text { program }^{\left({ }^{\prime}\right)}\end{array}$ & $\begin{array}{l}\text { As soon as tech- } \\
\text { nically feasible; } \\
\text { annually thereafter }\end{array}$ & $\begin{array}{l}\text { PNNL document } \\
(9 / 30 / 2000)\end{array}$ & $\begin{array}{l}40 \mathrm{CFR} \\
265.93(\mathrm{~d})(5) \text { and } \\
265.94(\mathrm{~b})\end{array}$ \\
\hline \multicolumn{4}{|c|}{$\begin{array}{l}\text { (a) Requirement was fulfilled during first year of sampling via published reports. Quarterly submittal of } \\
\text { data continues via HEIS. } \\
\text { (b) Required if exceedance occurs and is verified. }\end{array}$} \\
\hline
\end{tabular}




\subsection{References}

Agnew, S. F. 1997. Hanford Tank Chemical and Radionuclide Inventories: HDW Model Rev. 4. LA-UR-96-3860, Los Alamos National Laboratory, Los Alamos, New Mexico.

Anderson, J. D. 1990. A History of the 200 Area Tank Farms. WHC-MR-0132, Westinghouse Hanford Company, Richland, Washington.

Baker, V. R., B. N. Bjornstad, A. J. Busacca, K. R. Fecht, E. P. Kiver, U. L. Moody, J. G. Rigby, D. F. Stradling, and A. M. Tallman. 1991. "Quaternary Geology of the Columbia Plateau." In Quaternary Nonglacial Geology; Conterminous U. S., R. B. Morrison (ed.), The Geological of Society America, Vol. K-2, pp. 215-250, Boulder, Colorado.

Caggiano, J. A., Jr. 1992. Borehole Completion Data Package for Single-Shell Tanks: CY 1990. WHCSD-EN-DP-041, Westinghouse Hanford Company, Richland, Washington.

Caggiano, J. A. 1994. "Single-Shell Tanks." In Annual Report for RCRA Groundwater Monitoring Projects at Hanford Site Facilities for 1993, DOE/RL-93-88, pp. 4.13-1 through 4.13-50, prepared by Geoscienses Group, Westinghouse Hanford Company, Environmental Division for U.S. Department of Energy, Richland Operations Office, Richland, Washington.

Code of Federal Regulations, Title 40, Part 265. Interim Status Standards for Owners and Operators of Hazardous Waste Treatment, Storage, and Disposal Facilities.

Fecht, K. R., S. P. Reidel, and A. M. Tallman. 1987. "Paleodrainage of the Columbia River System on the Columbia Plateau of Washington State--A Summary." In Selected Papers on the Geology of Washington, J. E. Schuster (ed.), Bulletin 77, pp. 219-248, Washington Division of Geology and Earth Resources, Olympia, Washington.

Gee, G. W., M. J. Fayer, M. L. Rockhold, and M. D. Campbell. 1992. "Variations in Recharge at the Hanford Site." Northwest Science 66:237-250.

Gillespie, B. M. 1999. "Appendix C--Analytical Methods." In Hanford Site Groundwater Monitoring for Fiscal Year 1998, M. J. Hartman (ed.), PNNL-12086, Pacific Northwest National Laboratory, Richland, Washington.

Graham, M. J., M. D. Hall, S. R. Strait, and W. R. Brown. 1981. Hydrology of the Separations Area. RHO-ST-42, Rockwell Hanford Operations, Richland, Washington.

Hanlon, B. M. 1996. Waste Tank Summary Report for Month Ending September 30, 1996. WHC-EP0182-102, Westinghouse Hanford Company, Richland, Washington. 
Hartman, M. J. (ed.). 1999. Hanford Site Groundwater Monitoring for Fiscal Year 1998. PNNL-12086, Pacific Northwest National Laboratory, Richland, Washington.

Horton, D., and F. N. Hodges. 1999. Borehole Data Package for 1998 Wells Installed at Single-Shell Tank Waste Management Area U. PNNL-12126, Pacific Northwest National Laboratory, Richland, Washington.

Kupfer, M. J., A. L. Boldt, B. A. Higley, K. M. Hodgson, L. W. Shelton, B. C. Simpson, R. A. Watrous, M. D. LeClair, G. L. Borsheim, R. T. Winward, R. M. Orme, N. G. Colton, S. L. Lambert, D. E. Place, and W. W. Schulz. 1999. Standard Inventories of Chemicals and Radionuclides in Hanford Tank Waste. HNF-SD-WM-TI-740, Rev. 1, Lockheed Martin Hanford Corporation, Richland, Washington.

Lindsey, K. A. 1995. Miocene-to Pliocene-Aged Suprabasalt Sediments of the Hanford Site, SouthCentral Washington. BHI-00184, Bechtel Hanford, Inc., Richland, Washington.

Pacific Northwest National Laboratory. 1998. The Hanford Ground-Water Monitoring Project Quality Assurance Project Plan. QA Plan ETD-012, Rev. 1, Richland, Washington.

Resource Conservation and Recovery Act of 1976, as amended, Public Law 94-580, 90 Stat. 2795, 42 USC 6901 et seq.

Singleton, K. M., and K. A. Lindsey. 1994. Groundwater Impact Assessment Report for the 216-U-14 Ditch. WHC-EP-0698, Westinghouse Hanford Company, Richland, Washington.

State of Washington Department of Ecology, U.S. Environmental Protection Agency, and U.S. Department of Energy. 1989. Hanford Federal Facility Agreement and Consent Order Between the U.S. Environmental Protection Agency, the U.S. Department of Energy, and the State of Washington Department of Ecology, May 15, 1989, as amended. Olympia, Seattle, and Richland, Washington.

U.S. Department of Energy. 1988. Consultation Draft, Site Characterization Plan, Reference Repositom. Location. DOE/RW-0164, Vols. 1-9, Office of Civilian Radioactive Waste Management, Washington. D.C.

U.S. Department of Energy. 1989. Single-Shell Tank Closure/Correction Action Work Plan. DOE/RL89-16, Richland Operations Office, Richland Washington.

U.S. Department of Energy. 1992. U-Plant Source Aggregate Area Management Area Study (AAMSR). DOE/RL-91-52, Richland Operations Office, Richland, Washington.

U.S. Department of Energy. 1997. Vadose Zone Characterization Project at the Hanford Tank Farms U Tank Farm Report. GJO-97-1-TAR, GJO-HAN-8, Albuquerque Operations Office and Grand Junction Office, Grand Junction, Colorado. 
U.S. Department of Energy. 1998. Fiscal Year 1997 Annual Report for the 100-NR-2, 200-UP-1, and 200-ZP-1 Pump and Treat Operations and Operable Units. DOE/RL-98-38, Richland Operations Office, Richland, Washington.

U.S. Environmental Protection Agency. 1986a. Resource Conservation and Recovery Act (RCRA) Groundwater Monitoring Technical Enforcement Guidance Document (TEGD). OSWER-9950.1, Washington, D.C.

U.S. Environmental Protection Agency. 1986b. Test Methods for Evaluating Solid Wastes: Physical/Chemical Methods, $3^{\text {rd }} \mathrm{ed}$., SW-846, Office of Solid Waste and Emergency Response, Washington, D.C.

Washington Administrative Code, 173-303-400. Interim Status Facility Standards. Olympia, Washington.

Washington Administrative Code, 173-303-610. Closure and Postclosure. Olympia, Washington. 
Appendix

\section{Well Construction and Completion Summaries}




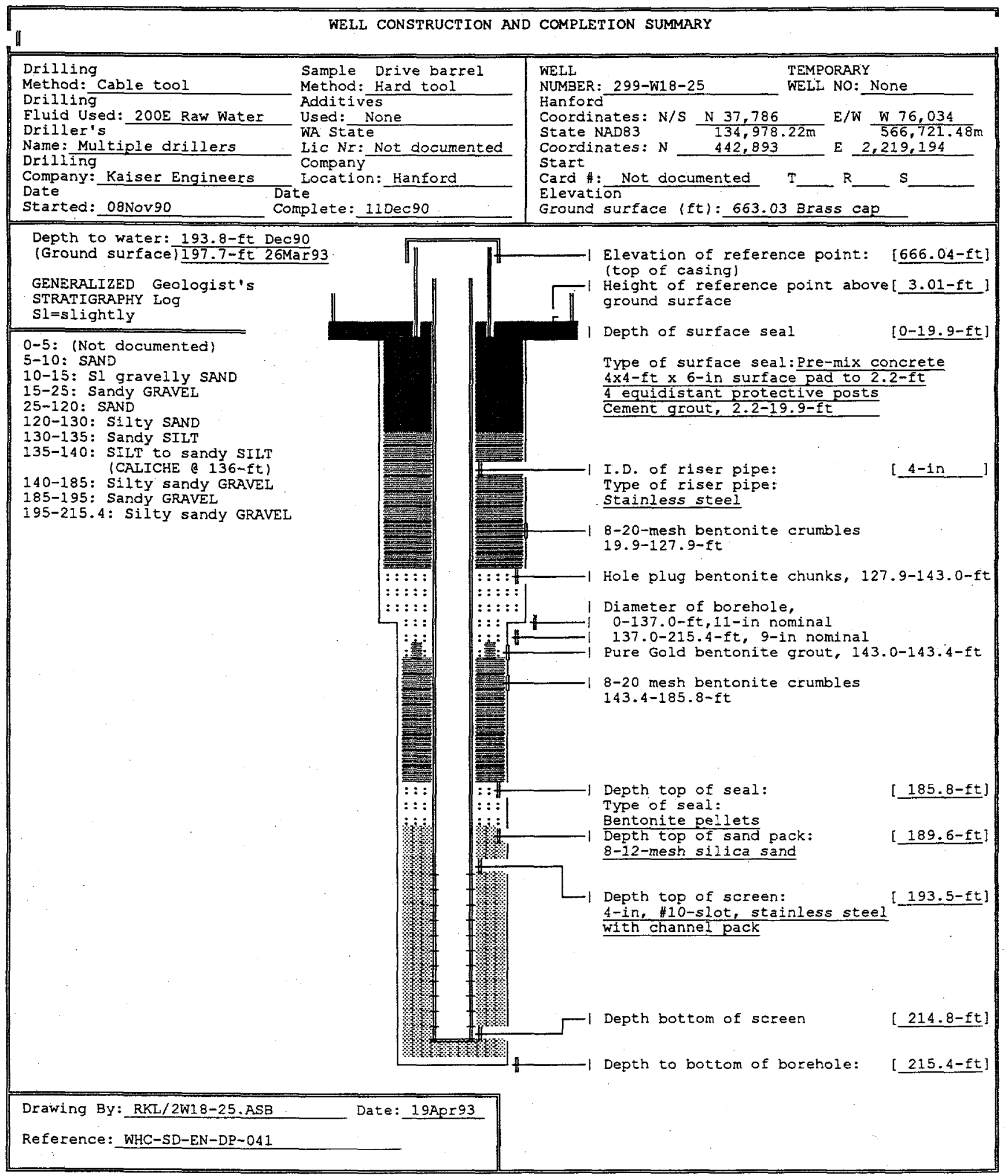


SUMMARY OE CONSTRUCTION DATA AND EIELD OBSERVATIONS RESOURCE PROTECTION WELL - 299-W18-25

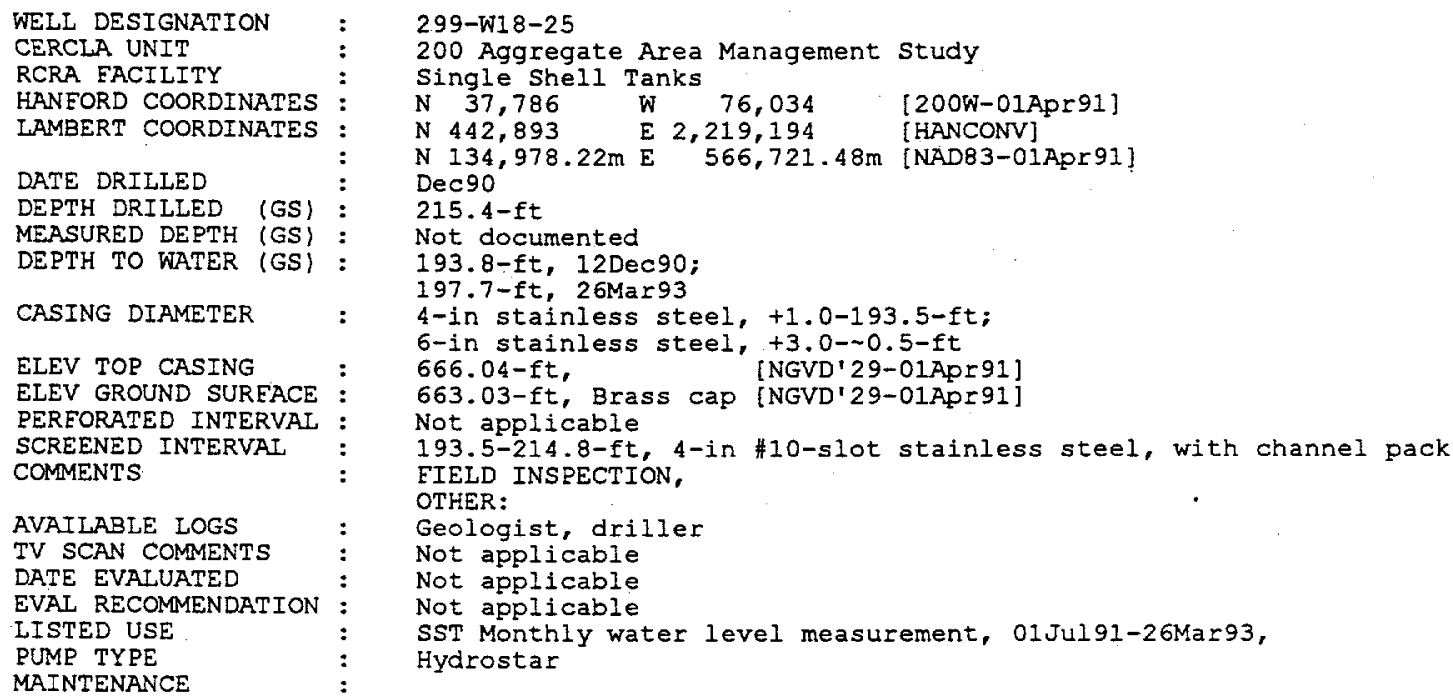




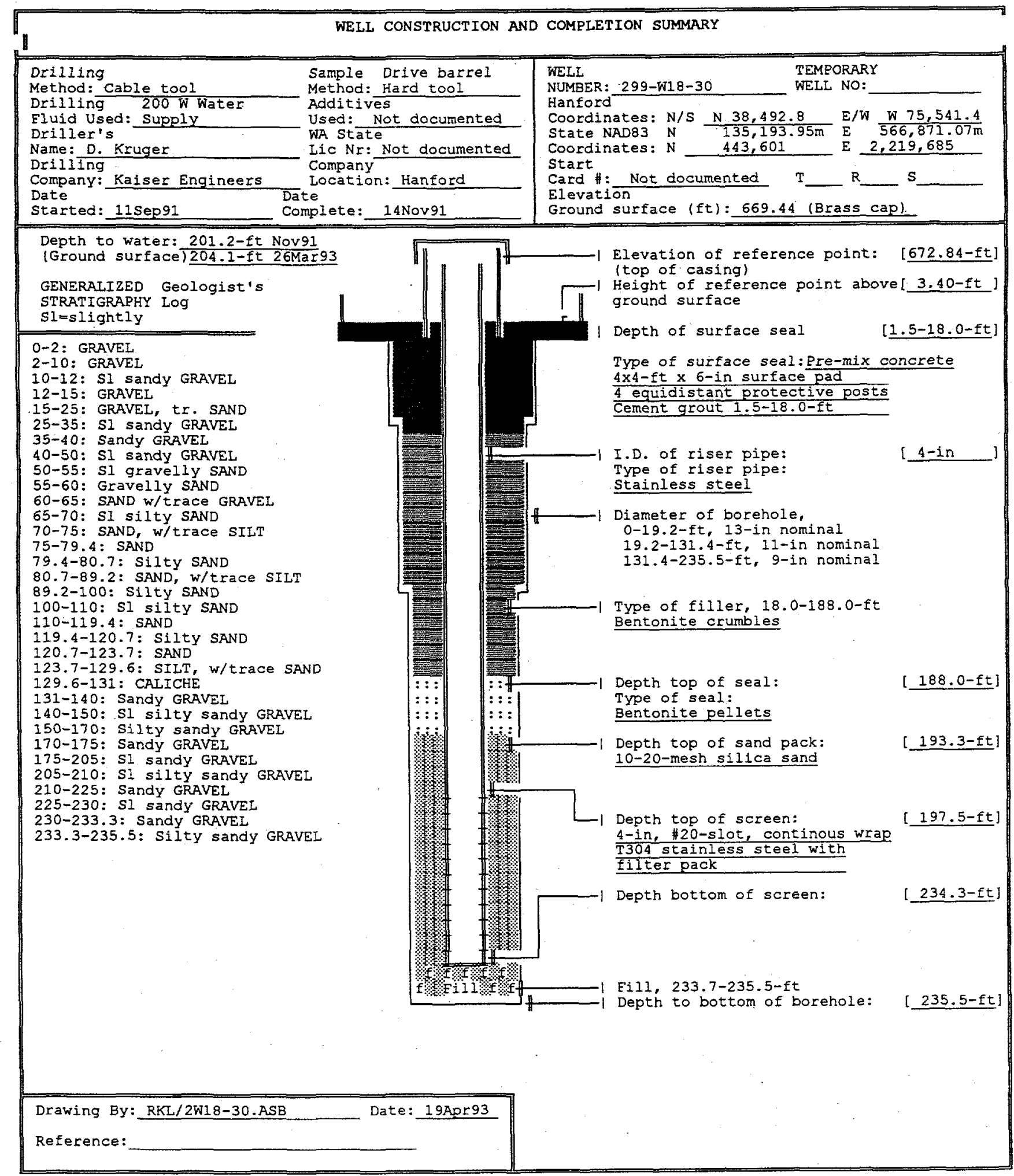


SUMMARY OE CONSTRUCTION DATA AND FIELD OBSERVATIONS RESOURCE PROTECTION WELL - 299-W18-30

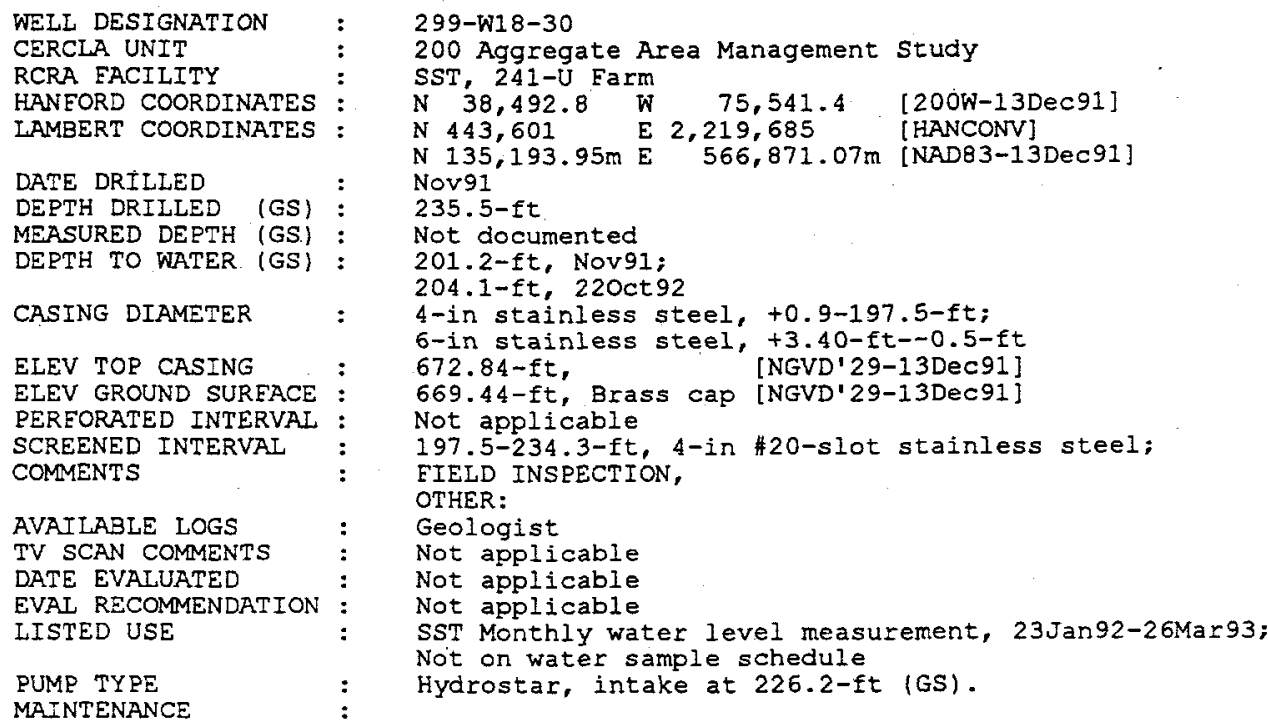

MAINTENANCE 


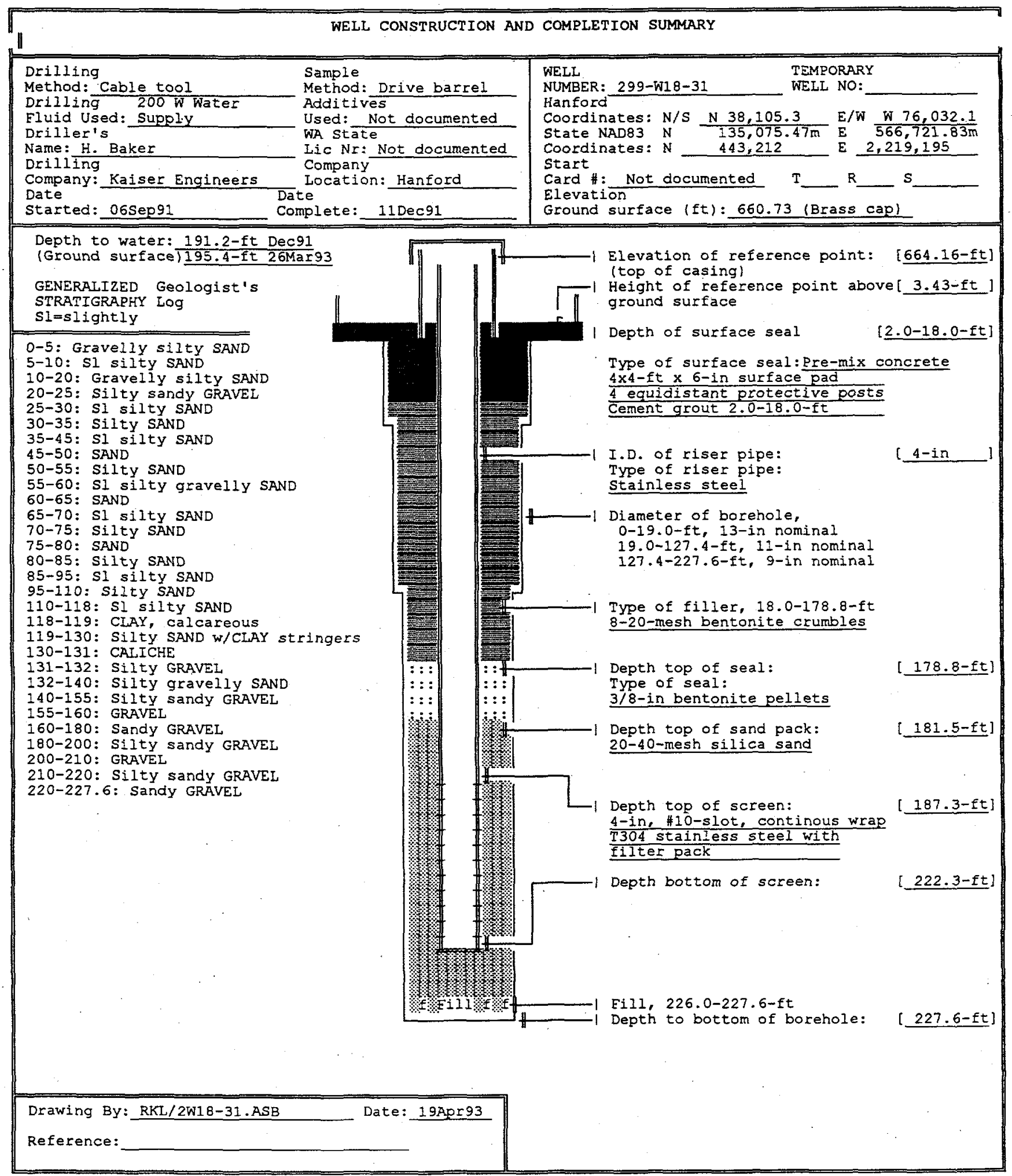


SUMMARY OF CONSTRUCTION DATA AND FIELD OBSERVATIONS RESOURCE PROTECTION WELL - 299-W18-31

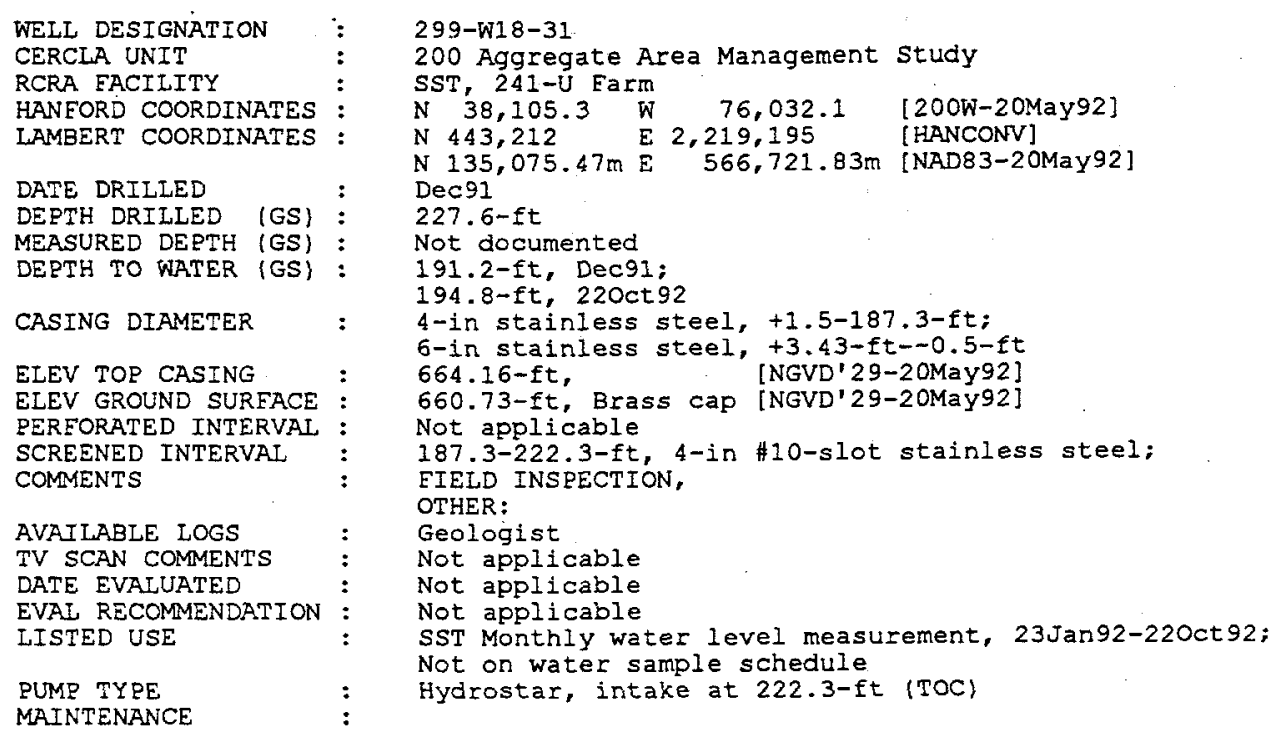




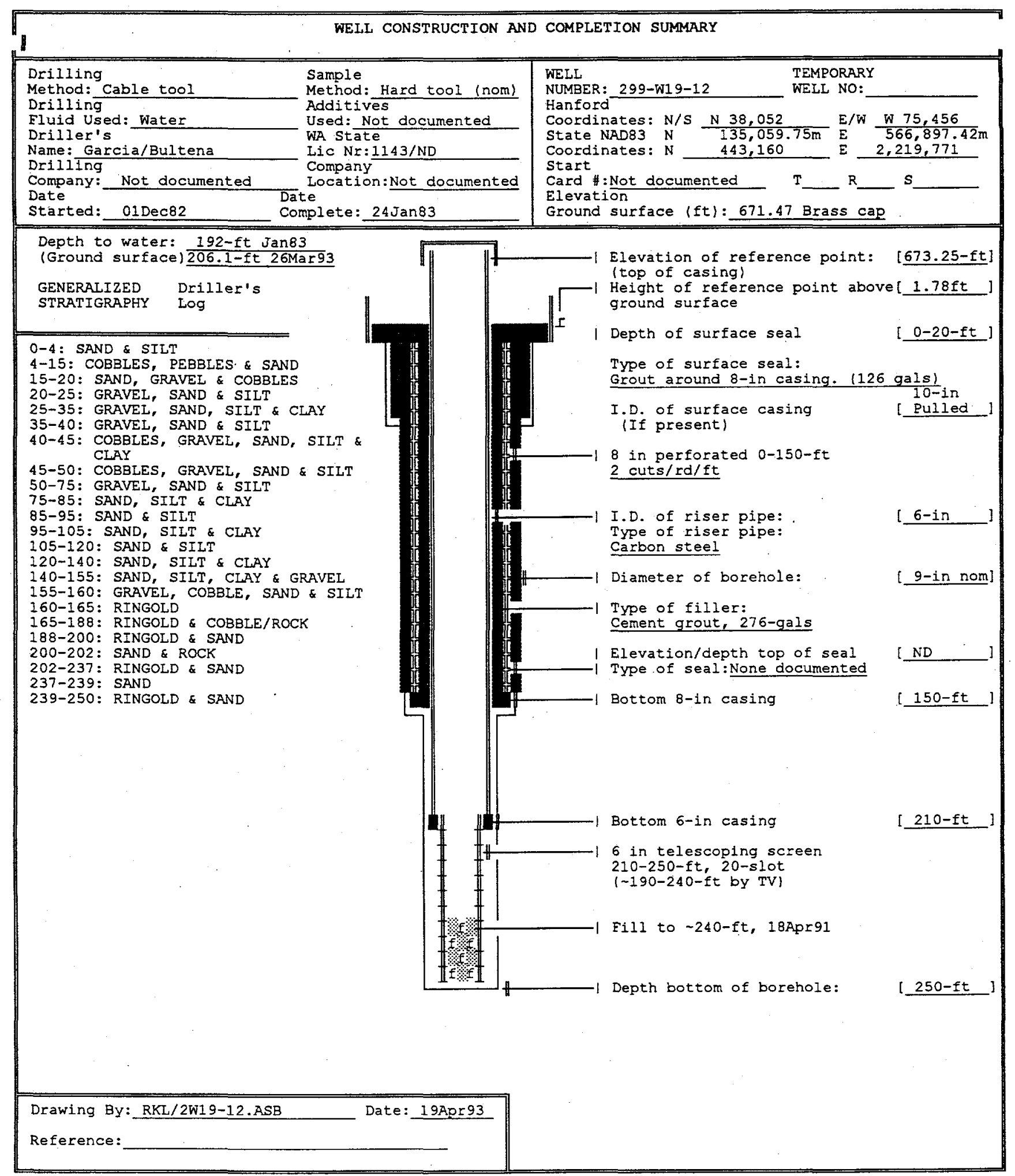


SUMMARY OE CONSTRUCTION DATA AND FIELD OBSERVATIONS RESOURCE PROTECTION WELL - 299-W19-12

WELL DESIGNATION CERCLA UNIT

RCRA EACILITY

HANFORD COORDINATES

LAMBERT COORDINATES

DATE DRILIED

DEPTH DRILLED (GS) :

MEASURED DEPTH (GS)

DEPTH TO WATER (GS) :

CASING DIAMETER

ELEV TOP CASING

ELEV GROUND SUREACE

PERFORATED INTERVAL :

SCREENED INTERVA

COMMENTS

\section{AVAILABLE LOGS}

TV SCAN COMMENTS

DATE EVALUATED

EVAL RECOMMENDATION :

LISTED USE

PUMP TYPE

MAINTENANCE
299-W19-12

200 Aggregate Area Management Study

Not applicable

N 38,052

N 443,160

$\mathrm{N} 135,059.75 \mathrm{~m}$

$\operatorname{Jan} 83$

$250-\mathrm{ft}$

239.7-ft, 18Apr91

192-ft, Jan83;

$206.1-\mathrm{ft}, 26 \mathrm{Mar} 93$

8 -in carbon steel, 0-150-ft

6-in carbon steel, +1.78-210-ft;

673.25-ft, [NGVD'29-06May91]

671.47 , Brass cap [NGVD'29-06May91]

8 -in casing $0-150-\mathrm{ft}$

6 -in telescoping $210-250-f t$

FIELD INSPECTION, 18API91,

6 -in carbon steel casing.

2 -ft cement pad. Four posts, capped and locked.

Identification stamped on brass marker in pad.

Not in radiation zone.

OTHER:

Driller

Not applicable

Not applicable

Not applicable

SST Monthly water level measurement, 02Apr90-26Mar93;

Not on water sample schedule,

Electric submersible 


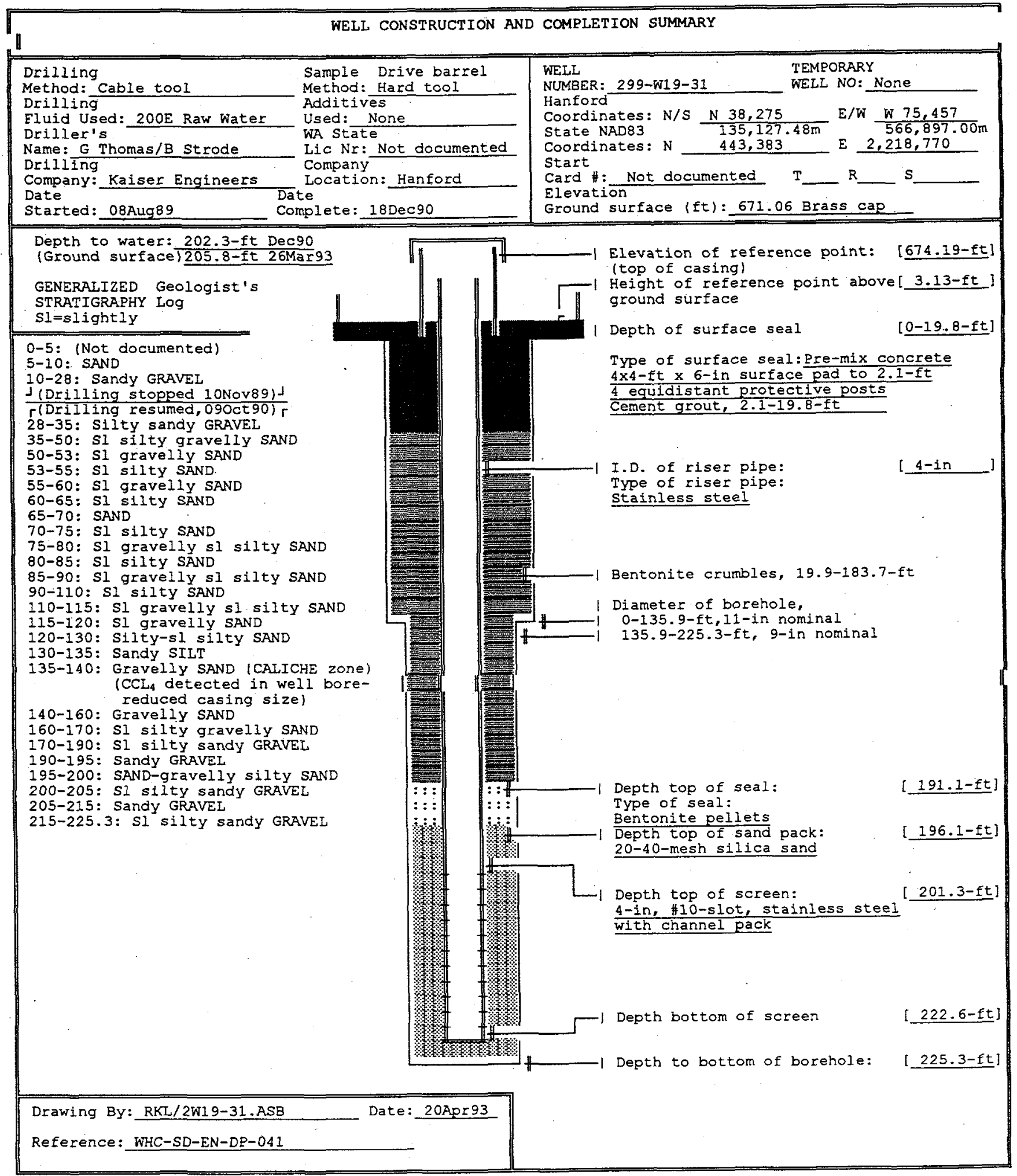


SUMMARY OE CONSTRUCTION DATA AND FIELD OBSERVATIONS RESOURCE PROTECTION WELL - 299-W19-31

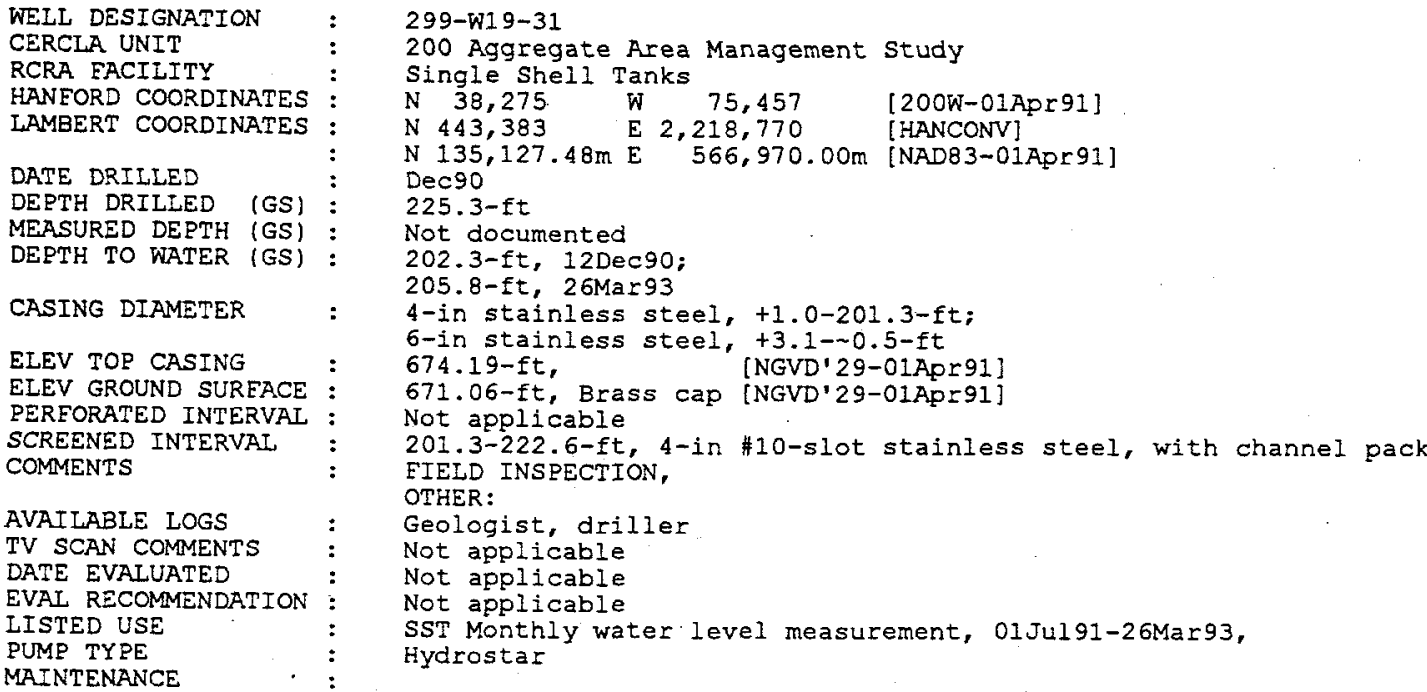







SUMMARY OF CONSTRUCTION DATA AND EIEID OBSERVATIONS

RESOURCE PROTECTION WELL - 299-W19-32

WELI DESIGNATION
CERCLA UNIT
RCRA EACIIITY
HANEORD COORDINATES
LAMBERT COORDINATES
DATE DRILIED
DEPTH DRIILED (GS)
MEASURED DEPTH (GS)
DEPTH TO WATER (GS)
CASING DIAMETER
ELEV TOP CASING
ELEV GROUND SUREACE
PEREORATED INTERVAL
SCREENED INTERVAL
COMMENTS
AVAILABLE LOGS
TV SCAN COMMENTS
DATE EVALUATED
EVAL RECOMMENDATION
LISTED USE
PUMP TYPE
MAINTENANCE

299-W19-32

200 Aggregate Area Management Study

Single Shell Tanks

N 37,887

W 75,459

[200W-01Apr91]

N 442,995

E $2,219,769$

[HANCONV]

N $135,009.29 \mathrm{~m} \mathrm{E} \quad 566,896.55 \mathrm{~m}$ [NAD83-01Apr92]

Jan 91

223.1-ft

Not documented

202.4-ft, 13Nov90;

$206.5-f t, 26 \mathrm{Mar} 93$

4-in stainless steel, +1.0-201.7-ft;

6 -in stainless steel, +3.0- 0.5-ft

674.90-ft, [NGVD'29-01Apr91]

671.92-ft, Brass cap [NGVD'29-01Apr91]

Not applicable

201.7-222.4-ft, 4-in \#10-slot stainless steel, with channel pack

EIELD INSPECTION,

OTHER:

Geologist, driller

Not applicable

Not applicable

Not applicable

SST Monthly water level measurement, 01Jul91-26Mar93,

Hydrostar 
0502374

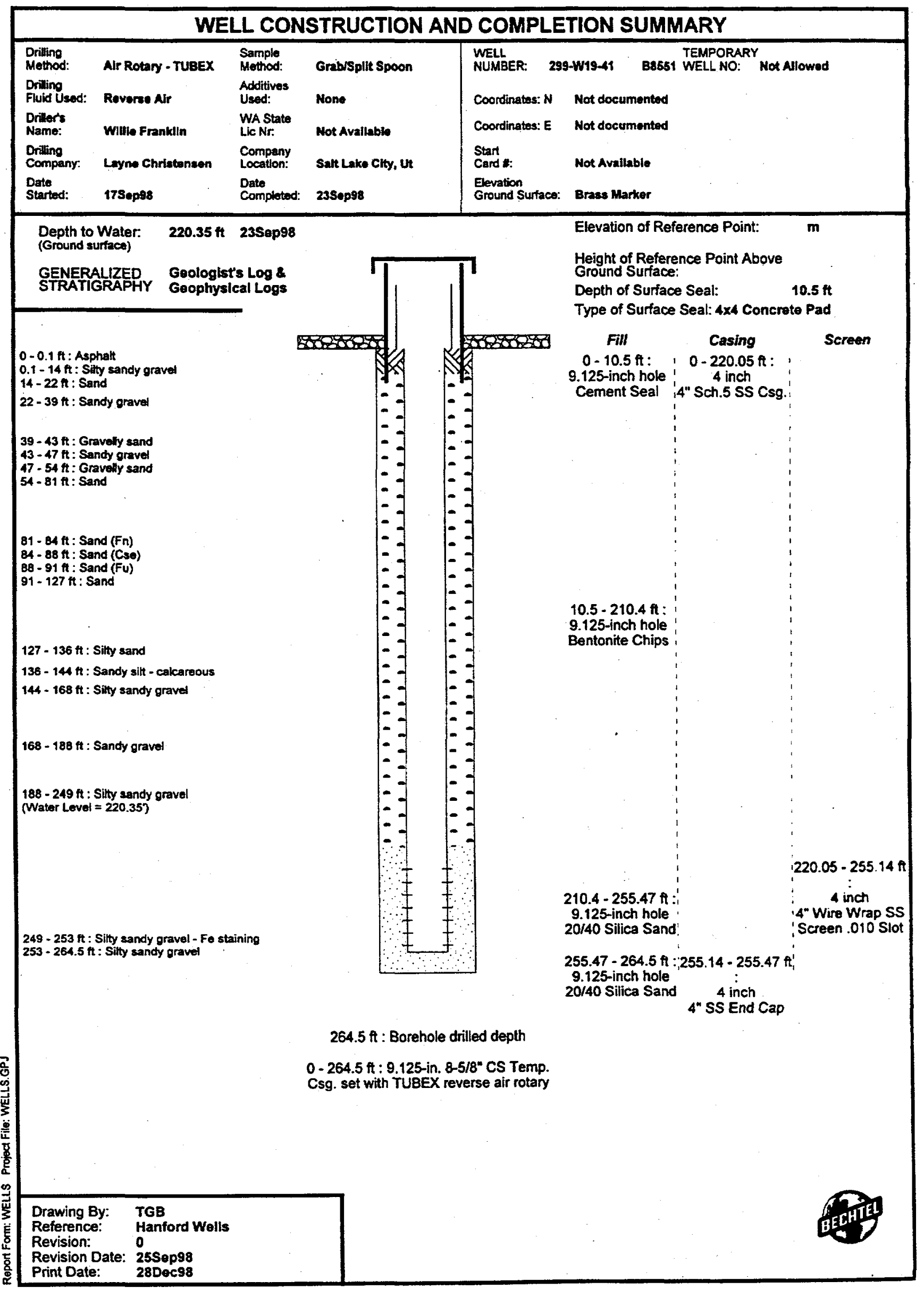




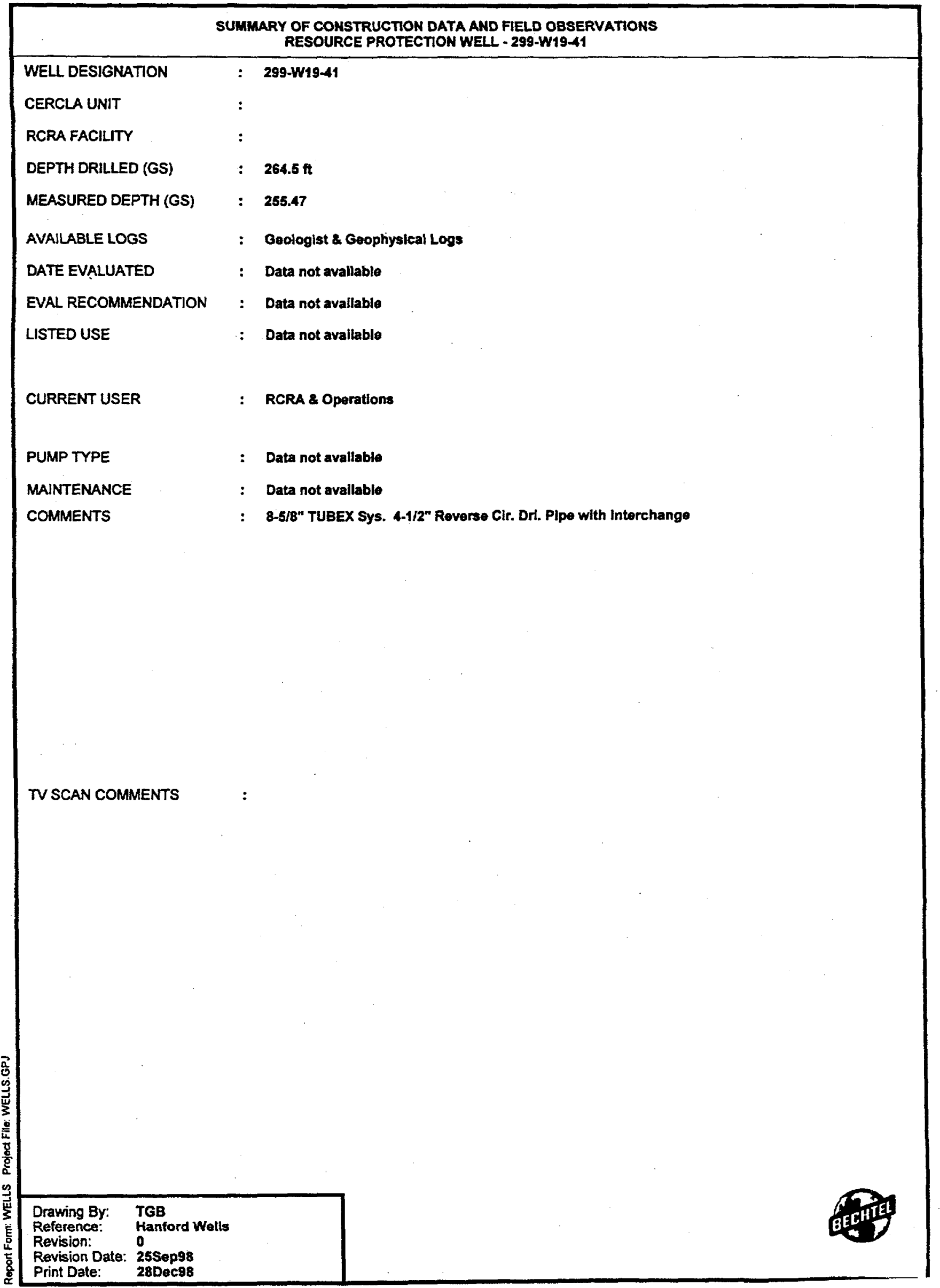

\section{A. 14}


0502376

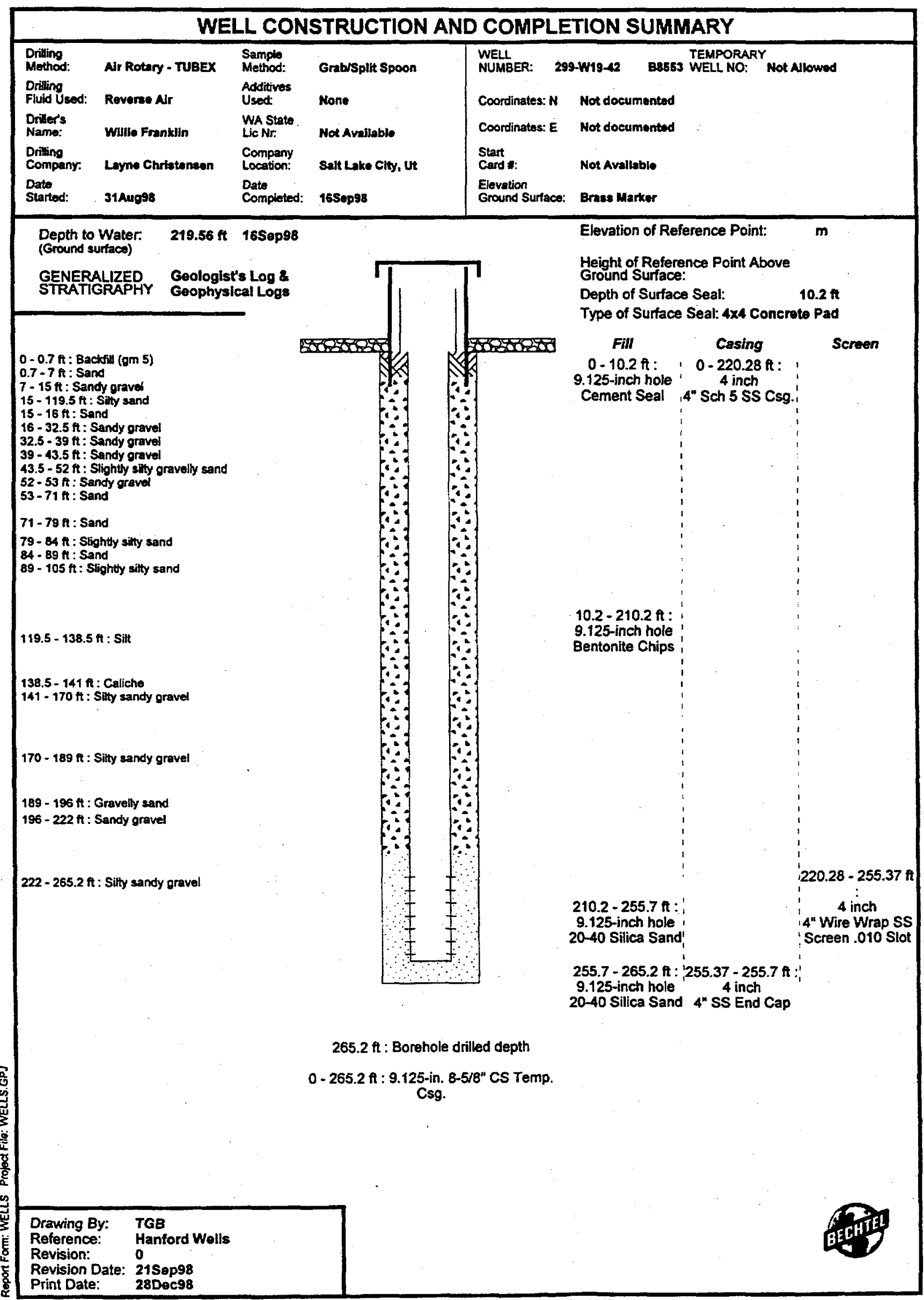




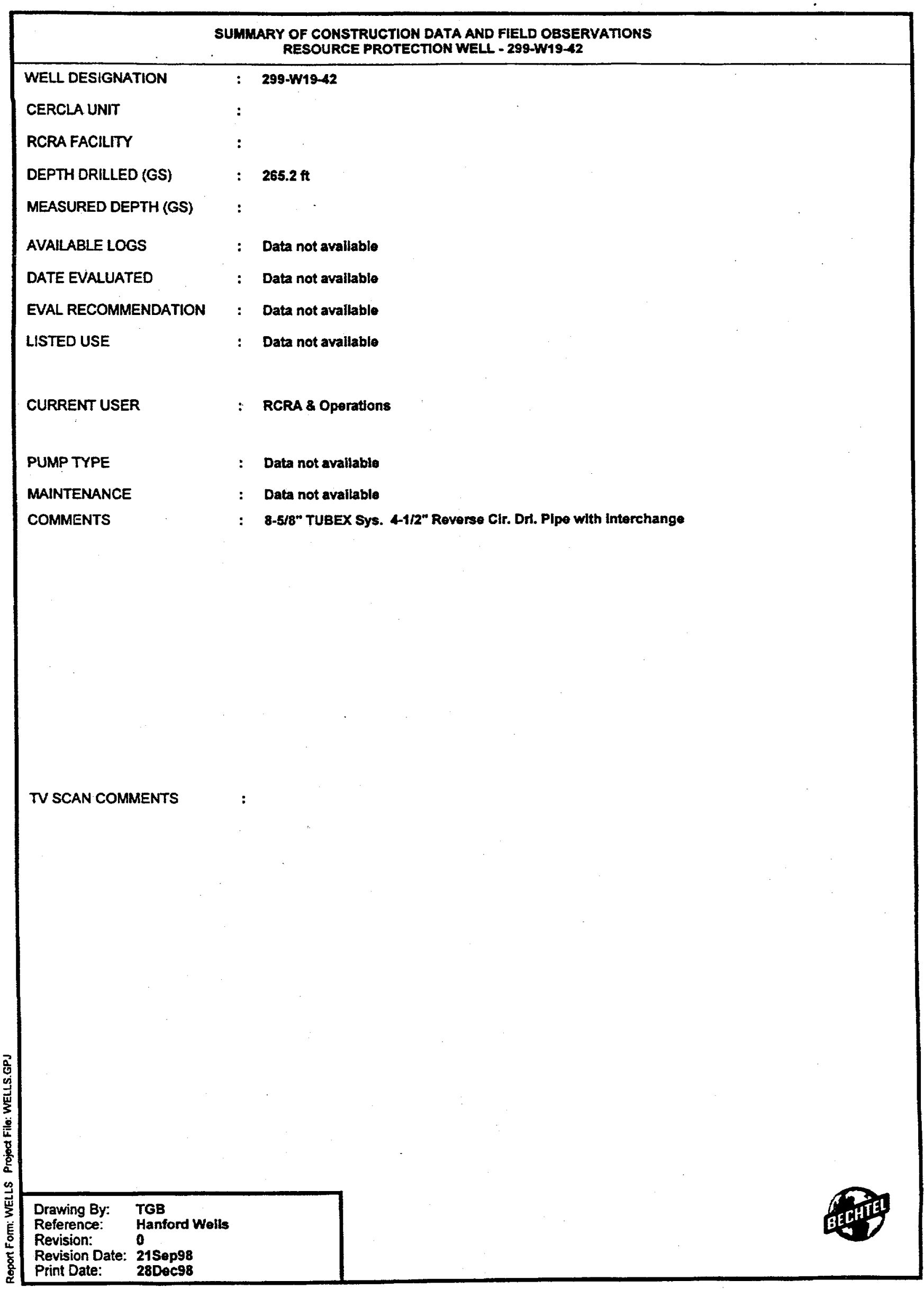




\section{Distribution}

No. of

Copies

No. of

Copies

ONSITE

8 DOE Richland Operations Office

M. J. Furman (7)

K. M. Thompson

2 Bechtel Hanford, Inc.

K. R. Fecht

G. C. Henckel, III
No. of

Copies

DOE - Office of River Protection
A. J. Knepp
H0-22

29. Pacific Northwest National Laboratory

$$
\text { C. J. Chou (3) }
$$

K6-81

H0-12

$\mathrm{H} 0-12$

M. J. Hartman

K6-96

F. N. Hodges (11)

K6-81

V. G. Johnson

K6-96

S. P. Luttrell (5)

K6-96

S. M. Narbutovskih

K6-96

H0-02

Information Release Office (7)

K1-06

Distr.1 